\title{
LIVING FREELY BEHIND BARS: REFRAMING THE DUE PROCESS RIGHTS OF TRANSGENDER PRISONERS
}

\author{
SARAH ORTLIP-SOMMERS*
}

Abstract

Federal constitutional jurisprudence, as it stands today, provides insufficient protections for transgender individuals who are incarcerated. Transgender prisoners face high rates of physical and sexual assault, harassment, and other mistreatment by state and federal prison officials and individuals incarcerated with them. Commonly pursued avenues for relief - namely the Eighth Amendment, the Equal Protection Clause of the Fourteenth Amendment, and the right to privacy_-present hurdles in the form of toohard-to-meet legal standards, and they perpetuate harmful stereotypes and cultural norms that should occupy no place in modern constitutional law. This Note proposes that, instead of relying on these inadequate constitutional claims to vindicate their rights, transgender prisoners and their advocates should consider litigating under the Due Process Clause of the Fifth and Fourteenth Amendments, articulating a right to live freely in accordance with one's gender identity. Recognition of such a right would enable plaintiffs to utilize more favorable substantive due process legal standards and eschew perpetuating outdated notions of gender within the law.

\footnotetext{
* J.D. 2021, Columbia Law School; B.A. 2018, Stanford University. Many thanks to Professor Philip Genty for his thoughtful comments and guidance during the writing process, and to the editorial staff of the Columbia Journal of Gender and Law for their wonderful work, as always. I am also indebted to the many people who have supported and inspired me throughout my law school experience, including Peggy Sommers and Danielle Ortlip.
} 


\section{INTRODUCTION}

Sonia Doe has known she is a transgender ${ }^{1}$ woman for nearly her entire life. ${ }^{2}$ After being formally diagnosed with gender dysphoria, ${ }^{3}$ she started hormone therapy and legally changed her name from the one given to her at birth to one that is traditionally feminine. ${ }^{4}$ Her driver's license now lists her legal name and includes a female gender marker. ${ }^{5}$ But after spending fifteen years as her true self, Sonia found herself unable to continue living freely as the woman she is. In March 2018, after she was sentenced to time in prison for offenses arising from an addiction to prescription painkillers, New Jersey officials placed Sonia in a prison facility for men. ${ }^{6}$

During Sonia's incarceration, prison staff consistently referred to her using male pronouns, denied her certain commissary items that were available to those living in the women's facility, beat her badly on multiple occasions, and subjected her to continual sexual harassment. ${ }^{7}$ More than a year after entering prison, she learned from her attorneys

\footnotetext{
${ }^{1}$ This Note uses the terms "transgender" or "trans" to refer to people whose gender identity differs from their sex assigned at birth. It does not assume that all people fitting this description use the label "transgender" themselves. Conversely, the term "cisgender" here refers to people whose gender identity aligns with the sex they were assigned at birth. Gender is conceptually different from sex. While sex may refer to a person's physiological characteristics, including their anatomy and hormone levels, gender is "a person's internal, personal sense of being" a man, woman, neither, or both. Transgender FAQ, GLAAD, https://www.glaad.org/transgender/transfaq [https://perma.cc/WGR2-YD8V].

${ }^{2}$ Gwen Aviles, Transgender Woman Who Alleged Abuse in Men's Prison To Be Moved to New Jersey Women's Facility, NBC News (Aug. 29, 2019), https://www.nbcnews.com/feature/nbc-out/transgenderwoman-who-alleged-abuse-men-s-prison-be-moved-n1047996 [https://perma.cc/ZY5C-KB6C].

${ }^{3}$ Gender dysphoria, a condition recognized by the Diagnostic and Statistical Manual of Mental Disorders (DSM-5), is the "severe distress" a person feels as a result of a discrepancy between sex assigned at birth and gender identity.

${ }^{4}$ Anna Orso, After Keeping Her in a Men's Prison for 17 Months, N.J. Will Move Transgender Inmate to Women's Facility, PHILA. InQUIRER (Aug. 29, 2019), https://www.inquirer.com/news/nj-move-transgenderprisoner-to-womens-facility-after-lawsuit-aclu-20190829.html [https://perma.cc/ZKD3-ZG2Q].

${ }^{5} I d$

${ }^{6} I d$.

${ }^{7} I d$.
} 
that she could file a request for a housing transfer, which she then did. She was never informed of a final decision. ${ }^{8}$

Sonia filed suit ${ }^{9}$ against the New Jersey Department of Corrections and certain prison officials in state court. ${ }^{10}$ Among other claims, she asserted a "right to live freely" under article I, paragraph $1^{11}$ of the state constitution:

By continuously misgendering her, inter alia by housing her solely in men's prisons, referring to her as male, using male pronouns to address her, and sometimes even explicitly telling her she is a man, Defendants are forcing Ms. Doe to live as a man and violating her right to live and express herself freely as a woman. ${ }^{12}$

Along with other forms of relief, Sonia sought a preliminary injunction in the form of a transfer to the New Jersey women's prison. ${ }^{13}$ In August 2019, before a judge could rule on the matter, the Department of Corrections agreed to move Sonia to the women's facility for the remainder of her sentence. ${ }^{14}$

Transgender people face myriad harms when they become incarcerated, as Sonia did. They are routinely denied access to medical care. They are placed in the wrong housing facility, subjecting them to heightened risks of violence and harm. They are ridiculed and

\footnotetext{
${ }^{8} I d$

${ }^{9}$ The author worked on Sonia's case as a legal intern for the ACLU of New Jersey during the summer of 2019.

${ }^{10}$ Verified Complaint, Jury Demand and Designation of Trial Counsel at 2, Doe v. N.J. Dep't of Corr., No. MER-L-001586-19 (N.J. Super. Ct. Law Div. Aug. 14, 2019).
}

${ }^{11}$ N.J. CONST. art. I, para. 1 ("All persons are by nature free and independent, and have certain natural and unalienable rights, among which are those of enjoying and defending life and liberty, of acquiring, possessing, and protecting property, and of pursuing and obtaining safety and happiness."). The New Jersey Constitution's reference to "life and liberty" is reminiscent of the Federal Due Process Clause. See U.S. CONST. amend. XIV, $\S 1$.

${ }^{12}$ Verified Complaint, Jury Demand and Designation of Trial Counsel, supra note 10, at 33.

${ }^{13}$ Brief in Support of Order to Show Cause with Temporary Restraints, Doe, No. MER-L-001586-19.

${ }^{14}$ Woman Who Is Transgender Will Be Transferred to Women's Prison, ACLU of N.J. (Aug. 29, 2019), https://www.aclu-nj.org/news/2019/08/29/woman-who-transgender-will-be-transferred-womens-prison [https://perma.cc/FUL9-6H59]. 
harassed by government officials and fellow prisoners. And they are often physically and sexually assaulted. The Constitution - along with other federal and state laws - provides avenues for challenging the mistreatment they endure, and many litigants are successful in defending their rights in court. But many more plaintiffs fail to meet the demanding legal standards shaped by decades of tangled case law, or their victories are the result of the law's reliance on antiquated ideas of gender that should play no part in our modern jurisprudence.

Sonia's story serves as an example of innovative litigation strategy when more commonly used frameworks fail to protect. To date, there has not been another claim articulating a similar right under state or federal law. This Note examines the current state of constitutional protections and proposes reframing transgender prisoners' - and all people's - rights under the Federal Constitution's Due Process Clause to recognize a right to live freely according to one's gender identity.

This Note proceeds in three parts. Part I provides relevant background information for understanding the challenges trans people face when they are incarcerated and how trans people have previously brought claims challenging conditions of their confinement, including housing placement that is inconsistent with their gender identity. Part II explains the inadequacy of constitutional frameworks often relied upon by transgender prisoners to bring such claims - including the Eighth Amendment, equal protection, and the right to privacy - at protecting trans individuals who have been mistreated in prison. Finally, Part III proposes a new framework under the Due Process Clause that transgender prisoners and their advocates may consider using to seek redress: the right to live freely according to one's gender identity. Jurists could apply the framework to many categories of claims brought by prisoners, as well as claims by non-incarcerated transgender individuals. ${ }^{15}$

\section{Incarceration While Transgender: Challenging Unjust Practices}

This Part illustrates the severe risks and harms faced by transgender people when they become incarcerated, including physical and sexual violence, mental health distress, and placement in solitary confinement. As numerous studies show, these problems tend to affect trans prisoners at higher rates than they do cisgender prisoners. ${ }^{16}$ This Part then provides pertinent background information about the litigation processes and legal

\footnotetext{
${ }^{15}$ See infra Part III.D for a discussion of the various contexts to which the right to live freely could be applied.
}

${ }^{16}$ See infra notes 19-27, 37 and accompanying text. 
standards that lie ahead for a prisoner, transgender or otherwise, seeking to bring a lawsuit against state or federal officials.

This Part discusses the experiences of the incarcerated transgender community as a whole, including people of all races and other identities. But it is important to note at the outset of this discussion that many of the struggles faced by trans prisoners are exacerbated when the prisoner is "multiply-marginalized," meaning they identify with two or more groups that have been historically disadvantaged and oppressed in society. ${ }^{17}$ It is therefore critical to keep intersectionality and its impact on transgender prisoners in mind throughout this analysis, as in any discussion of issues facing marginalized communities.

\section{A. The Transgender Prison Experience}

Discriminatory treatment of transgender people within the criminal justice system does not begin at the prison gates. As the Sylvia Rivera Law Project has explained, trans and gender-nonconforming communities are often targets of over-policing and profiling, resulting in high rates of imprisonment, police harassment, and violence as compared with cisgender populations. ${ }^{18}$ Nearly one in six transgender people face prison or jail time at least once, compared to about one in seventeen for the general population. ${ }^{19}$ The rate for trans women is even higher: More than one in five trans women have been

\footnotetext{
${ }^{17}$ Esinam Agbemenu, Medical Transgressions in America's Prisons: Defending Transgender Prisoners' Access to Transition-Related Care, 30 COLUM. J. GENDER \& L. 1, 2 (2015); see also Darren Rosenblum, "Trapped" in Sing Sing: Transgendered Prisoners Caught in the Gender Binarism, 6 Mich. J. Gender \& L. 499, 507 (2000) ("Transgendered [sic] prisoners' lives reflect the nature of multiply-oppressed identities in which the particularized nature of the oppression commingles with other oppressions to constitute a graver form of victimization.").
}

${ }^{18}$ See Transgender Incarcerated People in Crisis, LAMBDA LEGAL, https://www.lambdalegal.org/know-yourrights/article/trans-incarcerated-people [https://perma.cc/7SYZ-NM29].

\footnotetext{
${ }^{19}$ Exec. Off. of the President of the U.S., Economic Perspectives on Incarceration AND the Criminal JuSTICE SYSTEM 32 (2016),

https://obamawhitehouse.archives.gov/sites/whitehouse.gov/files/documents/CEA\%2BCriminal\%2BJustice\% 2BReport.pdf [https://perma.cc/Z2JR-V5WU]; NAT'L CTR. FOR TRANSGENDER EQUAL., A BLUEPRINT FOR EQUALITY: PRISON AND DETENTION REFORM (2012), https://www.transequality.org/sites/default/files/docs/resources/NCTE_Blueprint_for_Equality2012_Prison_ Reform.pdf [https://perma.cc/3JLJ-BGR7].
} 
incarcerated during their lives. ${ }^{20}$ Scholars have attributed this discrepancy to the presumption by law enforcement officers that trans women, particularly trans women of color, are likely sex workers. ${ }^{21}$ Police officers "regularly stop, harass, and demand identification from transgender women, regularly subject them to commands to disperse, and regularly arrest them for low-level offenses tied to suspicions of prostitution"-a phenomenon now colloquially known as "walking while trans." 22

Once convicted, sentenced, and incarcerated, transgender individuals continue to confront discriminatory treatment and abuse. Trans prisoners are uniquely vulnerable within the incarcerated community, where they face elevated risks of physical violence, sexual assault, and mental health problems. Respondents to a 2015 survey of trans prisoners by the National Center for Transgender Equality reported sexual assault by facility staff at rates five to six times higher than the general incarcerated population. ${ }^{23}$ They were also nine to ten times more likely to be sexually assaulted by another

\footnotetext{
${ }^{20}$ See NAT'L CTR. FOR TRANSGENDER EQUAL., supra note 19. Unsurprisingly—but importantly-nonwhite people report even higher rates of confinement. One in two Black transgender individuals has been to prison. LAMBDA LEGAL, TRANSGENDER Rights TOOLKIT 5 (2016), https://www.lambdalegal.org/sites/default/files/publications/downloads/2016_trans_toolkit_final.pdf [https://perma.cc/99S8-RWR7].
}

${ }^{21}$ Leonore F. Carpenter \& R. Barrett Marshall, Walking While Trans: Profiling of Transgender Women by Law Enforcement, and the Problem of Proof, 24 WM. \& MARY J. WOMEn \& L. 5, 6, 12 (2017).

${ }^{22}$ Id. at 6; Joey L. Mogul, Andrea J. Ritchie \& Kay Whitlock, Queer (In)Justice: The Criminalization OF LGBT PEOPLE IN THE UNITED STATES 61 (2011) (“Transgender women, particularly transgender women of color, are so frequently perceived to be sex workers by police that the term walking while trans, derivative of the more commonly known term driving while Black, was coined to reflect the reality that transgender women often cannot walk down the street without being stopped, harassed, verbally, sexually and physically abused, and arrested, regardless of what they are doing at the time."). The walking while trans phenomenon has been heavily documented and studied. See, e.g., Frank Galvan \& MoHSEn BaZARGan, InTERACtions of LATINA TRANSGENDER WOMEN WITH LAW ENFORCEMENT 7-8 (2012),

https://escholarship.org/content/qt62p795s3/qt62p795s3.pdf?t=m31fpk [https://perma.cc/75J5-E8XU] (describing interactions in which police officers "assumed" that trans women were prostitutes); ALLIANCE for a Safe \& Diverse DC, Move Along: Policing Sex Work in Washington D.C. 54 (2008), https://dctranscoalition.files.wordpress.com/2010/05/movealongreport.pdf [https://perma.cc/T4SA-MFYH] (finding that "negative police interactions were much more common for transgender people" than other populations); Amnesty Int'L, Stonewalled: Police Abuse and Misconduct Against Lesbian, Gay, BiseXual and Transgender People in the U.S. 20 (2005),

https://www.amnesty.org/download/Documents/84000/amr511222005en.pdf [https://perma.cc/2LR4-G923] (finding "a strong pattern of police unfairly profiling transgender women as sex workers").

${ }^{23}$ Sandy E. James et al., Nat’l Ctr. For Transgender Equal., The Report of the 2015 U.S. TRANSGENDER SURVEY 192 (2016), https://transequality.org/sites/default/files/docs/usts/USTS-Full-ReportDec17.pdf [https://perma.cc/G4YK-YURY]. 
prisoner. ${ }^{24}$ According to one Justice Department study, nearly forty percent of trans prisoners in state and federal prisons experience sexual victimization. ${ }^{25}$ Another study found that fifty-nine percent of trans individuals who were incarcerated in California men's prisons experienced sexual assault while incarcerated. ${ }^{26}$ In addition to enduring higher rates of physical and sexual violence than their cisgender peers, transgender prisoners are often targeted for violence because of their vulnerability. ${ }^{27}$

Transgender prisoners are usually assigned housing based on their genitals alone. ${ }^{28}$ For those who have not undergone gender-affirming surgery, this practice results in housing assignments that may not align with their true gender identity. Trans prisoners face distinct challenges when housed incongruously with their gender identity. Notably, they are often "singled out" for harassment and abuse. ${ }^{29}$ In men's prisons, in particular,

\footnotetext{
${ }^{24} I d$.

${ }^{25}$ Bureau of Just. Stat., U.S. Dep't of Just., Sexual Victimization in Prisons and Jails Reported by Inmates, 2011-12: Supplemental Tables: Prevalence of SeXual Victimization AmOng TransGender Adult InMATES (2014).
}

${ }^{26}$ Lori A. Sexton et al., Where the Margins Meet: A Demographic Assessment of Transgender Inmates in Men's Prisons, 27 JusT. Q. 835, 837-38 (2009).

${ }^{27}$ Richard Edney, To Keep Me Safe from Harm? Transgender Prisoners and the Experience of Imprisonment, 9 DEAKIN L. REV. 327, 332 (2004).

${ }^{28}$ While the standard default policy is housing placement according to a person's genitals, the Federal Bureau of Prisons and some states have implemented procedures for prisoners to request a housing transfer based on their gender identity. See, e.g., Jenny Gathright, The Guidelines for Protection of Transgender Prisoners Just Got Rewritten, NPR (May 12, 2018), https:/www.npr.org/sections/thetwo-way/2018/05/12/610692321/theguidelines-for-protection-of-transgender-prisoners-just-got-rewritten [https://perma.cc/Q8RE-U89X] (“'[T]he Transgender Executive Council 'will use biological sex as the initial determination' for facility assignment for transgender inmates, and a transgender inmate would be assigned to a facility based on their identified gender only 'in rare cases."'). Transgender prisoners are not always effectively informed of their right to such a request. See, e.g., Orso, supra note 4 (reporting that a transgender woman lived for over a year in a men's prison before learning of her right to request a housing transfer). Unsurprisingly, requests for transfers to a facility matching gender identity are very often denied. See, e.g., Josh Shaffer, Transgender Woman Has Asked to Be Moved from a Men's Prison. So Far, NC Has Said No., News \& OBSERVER (Feb. 20, 2019), https://www.newsobserver.com/news/state/north-carolina/article226472855.html [https://perma.cc/V9YH$6 \mathrm{ADH}]$ (reporting that a postoperative transgender woman's request to be moved to a women's prison was denied by the state).

${ }^{29}$ Lambda Legal, Testimony of Organizations Supporting LGBT Equality, Senate Judiciary Subcommittee on the Constitution, Civil Rights, and Human Rights 2 (June 9, 2012), 
rates of violence against trans women are high. They are consistent targets of severe attacks - including sexual assault — by officers and other incarcerated individuals, sometimes leading to litigation against their abusers. ${ }^{30}$ About twenty-one percent of trans women living in men's facilities suffer physical abuse while in prison, and twenty percent report sexual abuse. ${ }^{31}$ Indeed, "rape . . . is a distinct aspect" of many individuals' experiences in male prisons. ${ }^{32}$ Trans women are at "special risk" for physical injury, rape, and even death, due to cultural norms within prison facilities that "equate[] femininity with weakness." ${ }^{33}$

Transgender prisoners' physical and mental health may also suffer significantly as a result of treatment that conflicts with their gender identity. The trauma of being treated as something they are not can even, in extreme cases, lead some to resort to self-harm. One trans individual forced to live in a men's prison without access to gender-affirming surgery became so exasperated that she cut her scrotum with a razor and tried to squeeze one of her testicles out, only stopping when she began shaking intensely from the pain. ${ }^{34}$ In spite of cases like this, access to necessary medical care such as surgery and hormone therapy is often denied to many trans prisoners, regardless of housing placement. ${ }^{35}$

As a precautionary safety measure, transgender prisoners are often placed in administrative segregation, or solitary confinement. ${ }^{36}$ Trans prisoners - along with their

https://www.lambdalegal.org/sites/default/files/ltr_sjsccrhr_20120619_solitary-confinement.pdf [https://perma.cc/PAM6-CNAQ].

${ }^{30}$ See, e.g., Greene v. Bowles, 361 F.3d 290, 292 (6th Cir. 2004) (explaining that another prisoner "beat [the plaintiff] with a mop handle and then struck her with a fifty-pound fire extinguisher"); Hampton v. Baldwin, No. 18-CV-550, 2018 U.S. Dist. LEXIS 190682, at*7, *19 (S.D. Ill. Nov. 7, 2018) (describing an incident in which "a large man ran into [the plaintiff's] cell and began attacking her while she was on the toilet" and others wherein a lieutenant and an Internal Affairs officer forced the plaintiff to have sex with them "on a regular basis").

${ }^{31}$ LAMBDA LEGAL, supra note 29, at 2.

${ }^{32}$ Edney, supra note 27, at 332.

${ }^{33}$ Christine Peek, Breaking Out of the Prison Hierarchy: Transgender Prisoners, Rape, and the Eighth Amendment, 44 Santa Clara L. Rev. 1211, 1220 (2004).

${ }^{34}$ Keohane v. Jones, 328 F. Supp. 3d 1288, 1292 (N.D. Fla. 2018).

${ }^{35}$ Agbemenu, supra note 17, at 2.

${ }^{36}$ Peek, supra note 33, at 1220, 1239-40. 
lesbian, gay, and bisexual peers - are subjected to isolation at higher rates than cisgender, heterosexual prisoners. ${ }^{37}$ Sometimes officials place an individual in solitary temporarily while determining the appropriate long-term housing placement or during an investigation after a prisoner has been violently attacked.$^{38}$ Solitary confinement is also utilized as a means of punishment for trans prisoners. Whistleblower Chelsea Manning, who came out as trans in 2014 while serving a sentence for leaking confidential government documents, ${ }^{39}$ attempted suicide and was consequently placed in solitary. ${ }^{40}$ For someone already experiencing suicidal ideation, time in solitary confinement can make matters worse: Chelsea tried to take her own life again during her first week in isolation. $^{41}$

\footnotetext{
${ }^{37}$ According to a 2015 report by the U.S. Department of Justice, nearly twenty-eight percent of lesbian, gay, and bisexual prisoners (the report does not include statistics for trans prisoners) spent time in solitary, compared with almost eighteen percent of heterosexual prisoners. See Allen J. BECK, U.S. DeP'T OF Just., NCJ 249209, USE OF ReSTRICTIVE Housing IN U.S. PRISONS AND JAILS, 2011-12, at 4 tbl.3 (2015), https://www.bjs.gov/content/pub/pdf/urhuspj1112.pdf [https://perma.cc/MSP9-TAAH]. A 2015 survey of LGBTQ prisoners by the organization Black \& Pink found that eighty-five percent of respondents had been placed in solitary during their prison sentence, and about half had spent two or more years in isolation. JASON Lydon et Al., Black \& Pink, Coming Out of Concrete Closets: A Report on Black \& PinK's National LGBTQ PRISONER SURVEY 5 (2015),

https://dataspace.princeton.edu/bitstream/88435/dsp018p58pg71d/1/Coming-Out-of-Concrete-Closets-Blackand-Pink-October-21-2015.pdf [https://perma.cc/SYJ2-B779].
}

38 Jody Marksamer \& Harper Jean Tobin, Nat'L Ctr. For Transgender Equal., Standing With LGBT PRISONERS: An AdvocAte's Guide to ENDING AbuSE AND COMBATING IMPRISONMENT 11 (2013), https://dataspace.princeton.edu/jspui/bitstream/88435/dsp01tm70mx94p/1/JailPrisonsTransgender.pdf [https://perma.cc/P2XZ-FM99].

${ }^{39}$ Charlie Savage, Chelsea Manning Sentenced to Solitary Over Suicide Attempt, N.Y. TimES (Sept. 23, 2016), https://www.nytimes.com/2016/09/24/us/chelsea-manning-fort-leavenworth-attempted-suicide.html [https://perma.cc/AWG9-X8JL] [hereinafter Savage, Chelsea Manning Sentenced to Solitary Over Suicide Attempt]. In response to a lawsuit after her coming out, the Pentagon provided Chelsea with hormone therapy but required her to cut her hair to conform with "male standards" and to live in a facility with men. Id.; Charlie Savage, Chelsea Manning Tried Committing Suicide a Second Time in October, N.Y. Times (Nov. 4, 2016), https://www.nytimes.com/2016/11/05/us/chelsea-manning-tried-committing-suicide-a-second-time-inoctober.html [https://perma.cc/J8KL-BLR9] [hereinafter Savage, Chelsea Manning Tried Committing Suicide a Second Time in October].

${ }^{40}$ Savage, Chelsea Manning Sentenced to Solitary Over Suicide Attempt, supra note 39.

${ }^{41}$ Savage, Chelsea Manning Tried Committing Suicide a Second Time in October, supra note 39. 
Whatever the justification, any amount of time spent in solitary confinement can be detrimental to a prisoner's physical and mental health. ${ }^{42}$ The list of documented effects is long and includes symptoms such as anxiety, clinical depression, hallucinations, migraines, joint pain, and aggravation of preexisting medical conditions. ${ }^{43}$ Rates of selfharm and suicide are higher among those who have been held in solitary confinement than they are among the general prison population. ${ }^{44}$ The lasting consequences of the trauma of living in solitary confinement are also potentially dire. Prisoners may suffer permanent harm after living in isolation, which may severely impair their ability to reintegrate into society once they leave prison. ${ }^{45}$ Medical experts have found the psychological harm that results from solitary confinement tantamount to torture. ${ }^{46}$

Fortunately, despite its longstanding historical use, solitary confinement appears to be falling into disfavor-both internationally and within the United States. ${ }^{47}$ But, even as general awareness of the many consequences of solitary confinement is on the rise, reliance on the practice remains common across penal systems, and it may be generations before we see transgender prisoners immune from placement in solitary.

\section{B. Litigating as a Transgender Prisoner}

Trans prisoners, like all incarcerated individuals, face an uphill, obstacle-laden battle when it comes to suing the government for harms faced while behind bars. Prisoners have

\footnotetext{
42 World Health Organization [WHO], Prisons and Health 27 (Stefan Enggist et al. eds., 2014), https://apps.who.int/iris/bitstream/handle/10665/128603/Prisons\%20and\%20Health.pdf [https://perma.cc/VE5E-PGFE].

${ }^{43} I d$. at 28 .

${ }^{44} I d$. Prisoners already experience higher self-harm and suicide rates than the general population. Id.

${ }^{45}$ See id. at 31.

${ }^{46}$ MARKSAMER \& Tobin, supra note 38, at 3.

${ }^{47}$ WHO, supra note 42, at 27 ("International human rights law requires that the use of solitary confinement must be kept to a minimum and reserved for the few cases where it is absolutely necessary, and that it should be used for as short a time as possible."); Catherine Kim, Solitary Confinement Isn't Effective. That's Why New Jersey Passed a Law to Restrict It., Vox (July 11, 2019), https://www.vox.com/policy-andpolitics/2019/7/10/20681343/solitary-confinement-new-jersey [https://perma.cc/2CRV-L266] (detailing a recent New Jersey law severely restricting the use of solitary confinement, notably for "vulnerable populations" including the LGBTQ+ community).
} 
the right to bring federal constitutional civil rights challenges against state government ${ }^{48}$ officials under Section $1983 .{ }^{49}$ Constitutional suits against federal authorities, known as Bivens actions, ${ }^{50}$ are also permissible under some circumstances, although the courts have limited the availability of this path in recent years. ${ }^{51}$ Perhaps unsurprisingly, there are serious procedural hurdles to bringing such claims. The Prison Litigation Reform Act (PLRA) ${ }^{52}$ of 1996 created barriers to litigation by prisoners, introducing an administrative remedy exhaustion requirement, filing fees, a three-strikes provision, and a physical injury requirement. ${ }^{53}$ The PLRA was designed to reduce the number of legal actions against prisons by prisoners. ${ }^{54}$

Assuming these procedural hurdles are crossed, prisoners still do not enjoy full rights under the Federal Constitution while incarcerated. ${ }^{55}$ They may challenge the conditions of their confinement under the Eighth Amendment, which comes with its own stringent

\footnotetext{
${ }^{48}$ As of December 31, 2017, only about twelve percent of the total prison population is incarcerated in a federal institution. JENNIFER Bronson \& ANN CARSON, U.S. DEP'T OF Just., NCJ 252156, Prisoners IN 2017, at 3 (2019), https://www.bjs.gov/content/pub/pdf/p17.pdf [https://perma.cc/L9XS-D5E3].

${ }^{49}$ Civil Rights Act of 1871, 42 U.S.C. $§ 1983$; Peek, supra note 33, at 1231 n.166.

${ }^{50}$ See Bivens v. Six Unknown Named Agents of Fed. Bureau of Narcotics, 403 U.S. 388 (1971); Peek, supra note 33 , at 1231 .
}

${ }^{51}$ See, e.g., Ziglar v. Abbasi, 137 S. Ct. 1843 (2017) (limiting the viability of Bivens claims by prisoners who were unlawfully detained post-9/11). As one author explains, Ziglar dramatically reworked the standards for determining when a Bivens claim is available and — notably and dangerously_did not consider "whether alternative remedial mechanisms would be able to fill the gap left if a Bivens remedy was not provided." Julio Pereyra, Ziglar v. Abbasi and Its Effect on the Constitutional Rights of Federal Prisoners, 109 J. CRIM. L. \& CRIminology 395, 421 (2019). The Court also recently granted defendants "more flexibility" in raising a qualified immunity defense in Pearson v. Callahan, 555 U.S. 223, 230 (2009), reducing the possibility that a plaintiff will be able to fully litigate their claims. Id. at 409 n.108.

${ }^{52}$ Prison Litigation Reform Act of 1996, Pub. L. No. 104-134, 110 Stat. 1321 (codified in scattered sections of $11,18,28$, and 42 U.S.C.).

${ }^{53}$ ACLU, Know Your Rights: The Prison Litigation Reform Act (PLRA), https://www.aclu.org/sites/default/files/images/asset_upload_file79_25805.pdf [https://perma.cc/X5A2$6 \mathrm{UDH}]$.

${ }^{54}$ Rachel Poser, Why It's Nearly Impossible for Prisoners to Sue Prisons, New Yorker (May 30, 2016), https://www.newyorker.com/news/news-desk/why-its-nearly-impossible-for-prisoners-to-sue-prisons [https://perma.cc/JGJ5-BM2Z].

${ }^{55}$ Smith v. Hayman, No. 09-2602, 2012 U.S. Dist. LEXIS 44888, at*52 (D.N.J. Mar. 30, 2012), aff'd, 489 F. App'x 544 (3d Cir. 2012). 
legal standards. ${ }^{56}$ But prisoners' other constitutional rights may be curtailed by policies or regulations that are "reasonably related to legitimate penological interests," similar to rational basis review. There is no requirement that the challenged regulation or policy be the least restrictive means of serving those penological interests. ${ }^{58}$

Courts analyze four factors to determine the reasonableness of a challenged regulation or policy under Turner v. Safley: ${ }^{59}$

"First, there must be a 'valid, rational connection' between the prison regulation and the legitimate governmental interest put forward to justify it," and this connection must not be "so remote as to render the policy arbitrary or irrational." Second, a court must consider whether inmates retain alternative means of exercising the circumscribed right. Third, a court must take into account the costs that accommodating the right would impose on other inmates, guards, and prison resources generally. And fourth, a court must consider whether there are alternatives to the regulation that "fully accommodate[] the prisoner's rights at de minimis cost to valid penological interests." ${ }^{60}$

Notably, courts must "give weight, in assessing the overall reasonableness of regulations, to the [individual's] interest in engaging in constitutionally protected activity."

In practice, the Turner standard is quite favorable to prison administrators. But even under this demanding standard, prisoners' attempts to litigate challenges to mistreatment during their incarceration have not always been futile. For example, courts have extended the right to privacy to cover prisoners' medical information, albeit narrowly. ${ }^{62}$ The privacy right applies in this context when an incarcerated individual has an "unusual

\footnotetext{
${ }^{56}$ These standards are discussed in more detail infra in Part II.A.

${ }^{57}$ Turner v. Safley, 482 U.S. 78, 89 (1987); see also Pell v. Procunier, 417 U.S. 817, 822 (1974).

${ }^{58}$ Smith, 2012 U.S. Dist. LEXIS 44888, at*51.

${ }^{59} 482$ U.S. at $89-91$.

${ }^{60}$ Waterman v. Farmer, 183 F.3d 208, 213 (3d Cir. 1999) (citations omitted).

${ }^{61}$ DeHart v. Horn, 227 F.3d 47, 51 (3d Cir. 2000).

${ }^{62}$ See Doe v. Delie, 257 F.3d 309, 317 (3d Cir. 2001); Powell v. Schriver, 175 F.3d 107, 112-13 (2d Cir. 1999).
} 
medical condition" that, if disclosed, might expose them to harassment, discrimination, or violence. ${ }^{63}$ Prisoners also occasionally find success in the Eighth Amendment's prohibition on cruel and unusual punishments. ${ }^{64}$

These favorable decisions have not helped transgender prisoners, however, who have rarely been successful in vindicating their rights while behind bars. Many courts have dismissed claims brought by trans prisoners, including claims that they hold a fundamental right to health care to affirm their gender identity and Eighth Amendment rights against heightened risks of physical and sexual abuse. ${ }^{65} \mathrm{~A}$ few trans prisoners have prevailed in their litigation attempts. For example, courts have found that transgender status can trigger a "qualified right of privacy" for prisoners. ${ }^{66}$ But many more trans prisoners have failed. An Eighth Amendment challenge, in particular, may seem doomed from the start given the sheer number of past failed claims. ${ }^{67}$

Part II discusses claims brought by transgender prisoners, including the right to privacy and the Eighth Amendment, in greater detail. It includes a discussion of how Eighth Amendment legal standards are unfavorable to trans prisoners challenging conditions of their incarceration. It also examines other legal frameworks used by trans prisoners in the past that have not provided sufficient protections.

\section{Existing Constitutional Frameworks Fail to Protect Transgender Prisoners}

This Part examines legal claims trans prisoners commonly bring against state and federal prison officials and administrators. Included in this discussion are the Eighth Amendment, the right to privacy, the Equal Protection Clause, and some state law claims. As this Part illustrates, these claims are inadequate to the task of protecting transgender prisoners while incarcerated. Where a small number of trans prisoners have succeeded, their victories have often come with problematic implications or rested upon faulty assumptions.

\footnotetext{
${ }^{63}$ Smith, 2012 U.S. Dist. LEXIS 44888, at *52-53.

${ }^{64}$ U.S. CONST. amend. VIII.

${ }^{65}$ Franklin H. Romeo, Beyond a Medical Model: Advocating for a New Conception of Gender Identity in the Law, 36 Colum. Hum. RTs. L. Rev. 713, 747-48 (2005).

${ }^{66}$ Smith, 2012 U.S. Dist. LEXIS 44888, at *53; see also Powell, 175 F.3d at 112-13.

${ }^{67}$ See Romeo, supra note 65, at 748 n.130.
} 
It is important to note that this list is not necessarily exhaustive; there may be other avenues within the law to vindicate the rights of transgender prisoners. However, the claims included in this Part are among the most prevalent and thus ripe for a discussion of their merits—and, more importantly, their faults.

\section{A. The Eighth Amendment}

By far the most common constitutional claim brought by incarcerated transgender plaintiffs is under the Eighth Amendment. The Framers enacted the Eighth Amendment to protect incarcerated individuals from cruel and unusual punishments, yet unfortunately the provision falls short of protecting trans people from myriad harms at the hands of prison authorities. Extensive scholarship has examined the Eighth Amendment as applied to trans individuals in prison. ${ }^{68}$ This section attempts to distill some of the discussion to explain the Eighth Amendment's shortcomings in this critical context.

The Eighth Amendment protects prisoners from inhumane conditions and treatment while incarcerated through its prohibition on "cruel and unusual punishments." ${ }^{69}$ For example, a prison official may not use excessive physical force against any person in their custody. ${ }^{70}$ Fortunately, plaintiffs need not wait until they have actually been subjected to such punishment in order to bring Eighth Amendment claims $;{ }^{71}$ in Helling $v$. McKinney, the Supreme Court expanded Eighth Amendment protections to cover future damages to health and safety. ${ }^{72}$

The legal standard for Eighth Amendment challenges includes both objective and subjective components, a test that first emerged in its modern form in Estelle v. Gamble. ${ }^{73}$

\footnotetext{
${ }^{68}$ See generally, e.g., Peek, supra note 33 (discussing issues with the Eighth Amendment as applied to transgender prisoners who have been sexually assaulted while incarcerated); Agbemenu, supra note 17 (examining the Eighth Amendment's problems in the medical care context); Christoph M. Zhang, Biopolitical and Necropolitical Constructions of the Incarcerated Trans Body, 37 COLUM. J. GENDER \& L. 257 (2019) (considering the Eighth Amendment's shortcomings as a means of gaining access to genderaffirming care).

${ }^{69}$ U.S. CONST. amend. VIII.

${ }^{70}$ Farmer v. Brennan, 511 U.S. 825, 832 (1994); Hudson v. McMillian, 503 U.S. 1, 4 (1992).

${ }^{71}$ Peek, supra note 33, at 1231.

${ }^{72}$ Helling v. McKinney, 509 U.S. 25, 35 (1993).

${ }^{73}$ Estelle v. Gamble, 429 U.S. 97 (1976).
} 
First, the alleged deprivation of rights must be, objectively, "sufficiently serious." 74 The challenged action must result in the denial of "the minimal civilized measure of life's necessities. ${ }^{" 75}$ For a claim based on failure to prevent harm, the plaintiff must show that they are incarcerated under conditions posing a substantial risk of serious harm. ${ }^{76}$ Second, the prison official must have a "sufficiently culpable state of mind." "77 This is the socalled "deliberate indifference" test: To prevail on a claim, the plaintiff must show that the prison official acted with deliberate indifference to the plaintiff's health or safety. ${ }^{78}$ Infliction of pain that is either intentional or the result of deliberate indifference is considered "wanton" and violates the Eighth Amendment. ${ }^{79}$

The subjective component of the Estelle test is demanding enough to be difficult to satisfy, as it requires proof of knowledge on the part of the prison official. ${ }^{80}$ The official must have known of and disregarded a serious risk to the prisoner's health or safety. This standard requires, first, "actual notice of a prisoner's need for physical protection or medical care" ${ }^{81}$ and, second, the drawing of the inference that "a substantial risk of serious harm exists. ${ }^{.82}$

Interestingly, transgender prisoners' claims have helped shape the standards for Eighth Amendment violations more broadly. The Supreme Court's decision in Farmer v. Brennan, wherein a trans individual alleged Eighth Amendment violations after being

\footnotetext{
${ }^{74}$ Farmer, 511 U.S. at 834 (quoting Wilson v. Seiter, 501 U.S. 294, 298 (1991)); see also Hudson, 503 U.S. at 5 .

${ }^{75}$ Farmer, 511 U.S. at 834 (quoting Rhodes v. Chapman, 452 U.S. 337, 347 (1981)).

${ }^{76} \mathrm{Id}$. at 834; see also Helling, 509 U.S. at 35.

${ }^{77}$ Farmer, 511 U.S. at 834 (quoting Wilson, 501 U.S. at 297 ("[O]nly the unnecessary and wanton infliction of pain implicates the Eighth Amendment.")); see also Hudson, 503 U.S. at 8.
}

${ }^{78}$ Farmer, 511 U.S. at 834; Wilson, 501 U.S. at 302-03; see also Helling, 509 U.S. at 35; Hudson, 503 U.S. at 5; Estelle, 429 U.S. at 106.

\footnotetext{
${ }^{79}$ Kosilek v. Spencer, 889 F. Supp. 2d 190, 198 (D. Mass. 2012), aff'd, 740 F.3d 733, 773 (1st Cir. 2014), rev'd en banc, 774 F.3d 63 (1st Cir. 2014).

${ }^{80}$ Kosilek v. Nelson, No. 92-12820, 2000 U.S. Dist. LEXIS 13355, at*17-18 (D. Mass. Sept. 12, 2000).

${ }^{81}$ Layne v. Vinzant, 657 F.2d 468, 471 (1st Cir. 1981).

${ }^{82}$ Kosilek, 2000 U.S. Dist. LEXIS 13355, at*18 (quoting Farmer, 511 U.S. at 837); see also Barrie v. Grand Cnty., 119 F.3d 862, 868-69 (10th Cir. 1997).
} 
raped and beaten in a men's facility, ${ }^{83}$ softened the subjective standard established in Estelle, making it easier for plaintiffs to overcome. Of course, as the rest of this section discusses, the standard established in Farmer still does not pose an easy path to victory for trans plaintiffs. On the contrary, the standards remain somewhat convoluted and often reliant on dangerous assumptions.

The question before the Farmer Court was what level of culpability on the part of the prison official the deliberate indifference test requires. ${ }^{84}$ Whereas the Seventh Circuit had previously established a standard somewhat akin to criminal knowledge ${ }^{85}$ the Court in Farmer fashioned a more lenient standard analogous to criminal recklessness. The plaintiff argued they should only have to prove that a reasonable person should have understood the risk, but the Court decided mere negligence is not sufficient to establish an Eighth Amendment violation. ${ }^{86}$ The Court ultimately remanded the case for a consideration of whether the prison official " $\mathrm{kn}[\mathrm{ew}]$ that [the plaintiff] face[d] a substantial risk of serious harm and disregard[ed] that risk by failing to take reasonable measures to abate it." ${ }^{\prime 87}$

The post-Farmer Eighth Amendment standards are especially tricky for transgender plaintiffs challenging denials of access to medical care related to their transition, such as gender-affirming surgeries, mental health counseling, and hormone therapy. Estelle made providing prisoners medical care mandatory for officials, but the courts' mixed interpretations of ambiguous Eighth Amendment case law have left many trans litigants without protection. ${ }^{88}$ A significant number of courts accept gender dysphoria as a "serious medical need,"

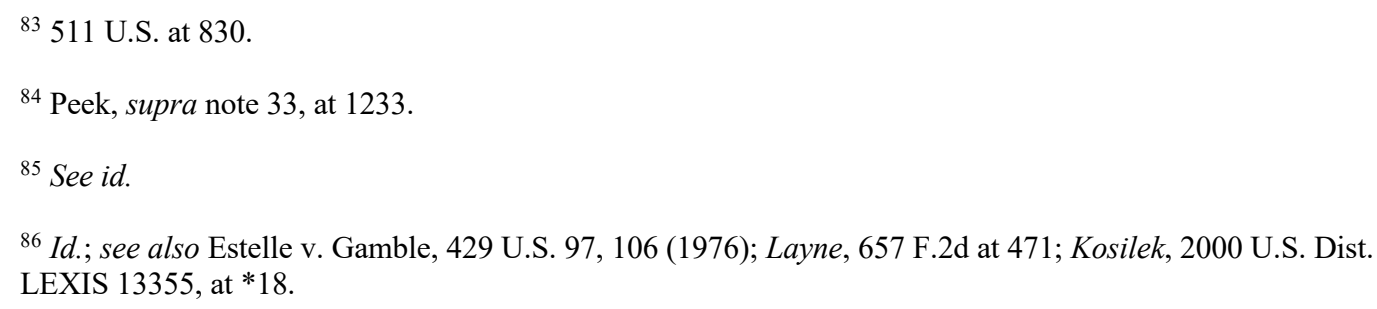

${ }^{88}$ Agbemenu, supra note 17, at 15-16 ("The standards courts apply range from a very broad definition that encompasses any condition that results in unnecessary and wanton infliction of pain to a narrow standard that recognizes a serious medical need only when it has been specifically diagnosed.").

${ }^{89}$ Zhang, supra note 68, at 272; see, e.g., De'lonta v. Johnson, 708 F.3d 520 (4th Cir. 2013); Fields v. Smith, 653 F.3d 550 (7th Cir. 2011); Allard v. Gomez, 9 F. App’x 793, 794 (9th Cir. 2001). 
disorder. ${ }^{" 90}$ However, passing that objective hurdle is often not enough, with many judges rejecting plaintiffs' claims on the ground that prison officials had not acted with subjective deliberate indifference.

In addition to perpetuating exacting legal standards, the courts' treatment of Eighth Amendment claims by trans plaintiffs has been troubling in other ways. Some courts have relied on a history of attempted suicide or self-mutilation in determining whether a transgender plaintiff's need for medical care met the seriousness standard. ${ }^{91}$ It is clearly disturbing that some transgender prisoners must resort to self-harm or wait until their mental and physical health drastically deteriorates in order to finally secure access to health care.

Meriwether v. Faulkner, although finding that the plaintiff's claim rose to the level of deliberate indifference, also teaches problematic lessons to courts confronting claims involving a denial of medical care for gender dysphoria. The plaintiff in Meriwether was denied "all medical treatment" while incarcerated and brought an Eighth Amendment claim against state officials. ${ }^{92}$ Although the district court decided gender dysphoria was not a serious medical need, ${ }^{93}$ the Seventh Circuit disagreed. Relying on case law from other circuits treating "psychiatric or psychological condition[s]" as presenting a serious medical need, ${ }^{94}$ the court found the plaintiff satisfied the first prong of the Estelle test, because " $[t]$ here is no reason to treat transsexualism differently than any other psychiatric disorder." 95

\footnotetext{
${ }^{90}$ Zhang, supra note 68, at 272 (quoting Meriwether v. Faulkner, 821 F.2d 408, 413 (7th Cir. 1987)); see also infra text accompanying notes 96-101.

${ }^{91}$ Zhang, supra note 68, at 295-97; see, e.g., Lewis v. Berg, No. 00-CV-1433, 2005 U.S. Dist. LEXIS 39571, at *26 (N.D.N.Y. Mar. 10, 2005) ("[Gender dysphoria] becomes a serious medical issue when the distress is intense enough to lead to self injury."); see also Elias Vitulli, Racialized Criminality and the Imprisoned Trans Body: Adjudicating Access to Gender-Related Medical Treatment in Prisons, 37 Soc. Just. 53, 60-61 (2010-11).

${ }^{92}$ Meriwether, 821 F.2d at 410.

${ }^{93} I d$. at 411 .

${ }^{94}$ See, e.g., Partridge v. Two Unknown Police Officers of Hous., 791 F.2d 1182, 1187 (5th Cir. 1986); Wellman v. Faulkner, 715 F.2d 269, 273 (7th Cir. 1983); Ramos v. Lamm, 639 F.2d 559, 574 (10th Cir. 1980); Inmates of Allegheny Cnty. Jail v. Pierce, 612 F.2d 754, 763 (3d Cir. 1979); Bowring v. Godwin, 551 F.2d 44, 47 (4th Cir. 1977).

${ }^{95}$ Meriwether, 821 F.2d at 413.
} 
The consequences of treating transgender identity as a mental disorder can be gravely dangerous. First, not every trans person experiences gender dysphoria. ${ }^{96}$ Precedential decisions like Meriwether may create more hurdles for prisoners who seek access to certain medical treatments but have not been formally diagnosed with gender dysphoria, ${ }^{97}$ not to mention the problematic moral implication that comes from conflating noncisgender identity with mental "illness." Gender is an inherent aspect of a person's identity, ${ }^{98}$ and one should not be labeled "disordered" for recognizing and embracing their most fundamental sense of self. The very notion of trans identity as a psychological disorder relies on the mistaken assumption that there are only two genders - male and female - and that nonconformity with that binary is somehow abnormal and capable of alleviation through medical treatment. ${ }^{99}$

While advocating for a legal system that does not rely on medicalizing trans identity, it is also worth noting that the recognition of gender identity disorder - now called gender dysphoria - enabled the courts to expand some "rudimentary" legal protections to the trans community. ${ }^{100}$ But though the American Psychiatric Association still classifies gender dysphoria as a mental disorder and it remains a part of the Diagnostic and Statistical Manual of Mental Disorders (DSM-5), ${ }^{101}$ we should expect that a fair legal system will not further antiquated and denigrating notions of what it means to identify as transgender.

In addition to these troubling implications, also of concern is that the Meriwether court explained that "a federal court should defer to the informed judgment of prison

\footnotetext{
${ }^{96}$ Agbemenu, supra note 17, at 9.

${ }^{97}$ See Romeo, supra note 65, at 730 ("Low-income transgender people who are unable to afford transfriendly healthcare and gender transgressive people who do not fall within the narrative of [gender dysphoria] prescribed by the medical establishment are unlikely to be able to avail themselves of legal protections that have emerged from the use of th[e medical] model" of transgender identity).

${ }^{98}$ See supra note 1.

${ }^{99}$ See Romeo, supra note 65, at 724-25.

${ }^{100} I d$. at 726.

101 What is Gender Dysphoria?, AM. PsYCHIATRIC Ass'N (Feb. 2016), https://www.psychiatry.org/patientsfamilies/gender-dysphoria/what-is-genderdysphoria\#: : text=The\%20Diagnostic\%20and\%20Statistical\%20Manual,and $\% 20$ for $\% 20$ adolescents $\% 20$ and $\% 20$ adults.\&text $=\mathrm{A} \% 20$ marked $\% 20$ incongruence $\% 20$ between $\% 20$ one's,and $\% 2$ For $\% 20$ secondary $\% 20$ sex $\% 2$ 0characteristics [https://perma.cc/Z2KT-C5XK].
} 
officials as to the appropriate form of medical treatment." 102 Other courts have afforded similar deference in response to First Amendment actions by cisgender prisoners. ${ }^{103}$ Historically, prison officials have not shown the recognition and willingness required to make informed, thoughtful decisions regarding medical care for transgender individuals. "Thus, while seemingly favorable to transgender prisoners, the Meriwether decision leaves open the chilling and very present possibility that prison officials could provide inappropriate or abusive care to fulfill their constitutional obligations." ${ }^{.104}$

Meriwether was decided in 1987. Yet courts' attitudes have not substantially progressed in more than thirty years when it comes to medical care for transgender prisoners, and the legal standards governing the Eighth Amendment remain onerous. Michelle Kosilek's protracted litigation, discussed below, illustrates a few of the battles that may lie ahead for the twenty-first-century trans prisoner hoping to secure their Eighth Amendment right to transition care.

The procedural history of the Kosilek litigation is complex and spans multiple decades. ${ }^{105}$ Michelle first filed a lawsuit in 1992 against Massachusetts officials under the Eighth Amendment seeking access to medical treatment for gender dysphoria that could possibly lead to gender-affirming surgery and/or hormone therapy. ${ }^{106}$ In 2002 , the district court rejected Michelle's motion for summary judgment on her claims of deliberate indifference. ${ }^{107}$ Although the court agreed that Michelle's gender dysphoria manifested a

102 Meriwether v. Faulkner, 821 F.2d 408, 414 (7th Cir. 1987) (emphasis added).

${ }^{103}$ See, e.g., Brown v. Johnson, 743 F.2d 408, 412-13 (6th Cir. 1984) (“[W]e will try not to second-guess prison administrators on matters relating to prison security, even when those matters affect the constitutional rights of inmates in a manner we find discomforting. As long as prison authorities present evidence to support their judgment that prison security will be undermined in the absence of a challenged regulation, we will not substitute our judgment for theirs." (citations omitted)). In Brown, the plaintiff challenged prison officials' prohibition of certain religious worship services. The Sixth Circuit affirmed the lower court's holding that the ban on worship was reasonably related to the state's interest in prison security. Id. at 413.

${ }^{104}$ Zhang, supra note 68, at 273.

${ }^{105}$ For a more detailed discussion and analysis of the Kosilek litigation, see generally id. at 277-99.

${ }^{106}$ Id. at 277; Kosilek v. Maloney (Kosilek I), 221 F. Supp. 2d 156, 159 (D. Mass. 2002). Over the next few decades, a string of Massachusetts Department of Corrections commissioners repeatedly and adamantly refused to provide gender-affirming surgery to individuals in prison or to accept advice from experts who recommended the surgery. The commissioners' inaction made progress in the Kosilek litigation slow and the odds of any prisoner receiving the surgery slim to none. See Zhang, supra note 68, at 277-80.

${ }^{107}$ Kosilek I, 221 F. Supp. 2d at 195. 
"serious medical need" and she had not been offered adequate treatment, thus satisfying the objective component of the Eighth Amendment standard, it concluded she had not shown that the defendant had acted with deliberate indifference in denying her care. ${ }^{108}$ The Department of Corrections Commissioner, the judge decided, "had not actually inferred that there would be a substantial risk of serious harm" as a result of his actions, despite his objective knowledge of Michelle's situation. ${ }^{109}$

By this time, Michelle had filed a second lawsuit in response to inaction by the state. ${ }^{110}$ In 2012, the district court found that state officials had acted with deliberate indifference by continuing to deny Michelle gender-affirming surgery when they knew she faced a substantial risk of serious harm, and that the Department of Corrections' "security concerns" were pretextual. ${ }^{111}$ The court accordingly issued an injunction ordering the Department to provide her the procedure. ${ }^{112}$ The Department appealed to the First Circuit, which initially affirmed in $2014 .{ }^{113}$ However, the full court later reversed the decision upon rehearing en banc, ${ }^{114}$ disagreeing with the district court's analysis of both prongs of the Estelle test. ${ }^{115}$ Unlike the district court, the First Circuit afforded great deference to the Department and found their "concerns about safety and security" were reasonable and not pretextual. ${ }^{116}$

If the Kosilek cases signal anything definitively, it is that the law guiding judges on Eighth Amendment standards for transgender prisoners is as yet unsettled. Trans prisoners who have been denied access to medical care should not have to rely on such troublesome law. As public awareness of trans issues and respect for trans people grow,

\footnotetext{
${ }^{108} I d$. at $184-85,195$.

${ }^{109}$ Id. at $190-91$.

${ }^{110}$ Kosilek v. Spencer (Kosilek II), 889 F. Supp. 2d 190 (D. Mass. 2012); Zhang, supra note 68, at 278.

${ }^{111}$ Kosilek II, 889 F. Supp. 2d at 238-39.

${ }^{112}$ Zhang, supra note 68, at 280.

${ }^{113}$ Kosilek v. Spencer (Kosilek III), 740 F.3d 733, 773 (1st Cir. 2014).

${ }^{114}$ Kosilek v. Spencer (Kosilek IV), 774 F.3d 63, 63 (1st Cir. 2014) (en banc).

${ }^{115}$ Zhang, supra note 68, at 281.

${ }^{116}$ See Kosilek IV, 774 F.3d at 93-96. The Supreme Court declined to grant certiorari. Kosilek v. O'Brien, 135 S. Ct. 2059 (2015).
} 
government officials are required to learn more about their plight, ${ }^{117}$ and new studies document the dangers posed to trans people while incarcerated, it is not hard to imagine a world in which the subjective component of the deliberate indifference test is a mere bump on the road to justice. But in today's legal landscape, expecting government actors to be aware enough of potential harm to take the necessary precautions to ensure trans individuals avoid mistreatment in prison - and expecting judges to recognize that awareness - is simply not feasible.

\section{B. Other Claims}

While the Eighth Amendment is the most ubiquitous claim brought by transgender prisoners, it is not the only existing path to legal relief. This section outlines lesser-used claims, including the right to privacy, equal protection, and some state law claims. As with the Eighth Amendment, these options have proven to be unpromising for trans individuals suffering mistreatment while incarcerated.

\section{The Right to Privacy}

Prisoners enjoy a constitutionally protected right to privacy, violations of which are subject to the standard of review established in Turner. ${ }^{118}$ In the prison context, courts have decided prisoners hold a right to maintain the confidentiality of certain medical records. ${ }^{119}$ In some circumstances, this right extends to information about a prisoner's transgender status. The Second Circuit in Powell v. Schriver, for example, found prison officials' disclosure that the plaintiff was trans to staff members and others who were incarcerated served no legitimate penological interest. ${ }^{120}$ The court specifically cited the

\footnotetext{
${ }^{117}$ Under the Prison Rape Elimination Act of 2003, 34 U.S.C. $\S \S 30301-09$, prison staff members must undergo training related to issues concerning LGBTQ+, gender nonconforming, and intersex people. NAT'L Ctr. For Transgender Equal., LGBT PeOple and the Prison Rape Elimination ACt 3 (2012), https://www.transequality.org/sites/default/files/docs/resources/PREA_July2012.pdf [https://perma.cc/KKZ3P69A].

118 Powell v. Schriver, 175 F.3d 107, 112 (2d Cir. 1999) (“A regulation that 'impinges on inmates' constitutional rights' is therefore valid only if it 'is reasonably related to legitimate penological interests." (quoting Turner v. Safley, 482 U.S. 78, 89 (1987))).

${ }^{119} \mathrm{Id}$.

${ }^{120} I d$. at 113 . The court was actually less inclined to find privacy protections for the plaintiff's HIV-positive status, which was also disclosed to other prisoners and staff. $I d$. Other courts have found HIV-positive status worthy of privacy protections. See, e.g., Doe v. Delie, 257 F.3d 309, 317 (3d Cir. 2001).
} 
potential for "inmate on inmate violence" as a reason for preserving confidentiality in this context. ${ }^{121}$

Although the right to privacy was useful to the Powell plaintiff, the court's decision does not provide adequate guarantees of protection for future litigants for a few critical reasons. First, the court maintained that it did not mean to "suggest that a prison official's disclosure of an [individual's] transsexualism — or, for that matter, the failure of a prison official to help a prisoner conceal her transsexualism where that condition is easily discernable - cannot in some circumstances be viewed as reasonably related to legitimate penological concerns." ${ }^{122}$ A less agreeable judge could rule against a plaintiff in a case similar to Powell.

Second, Powell involved a plaintiff who was HIV-positive. ${ }^{123}$ Though the court did not conclude that the plaintiff held a constitutional right to confidentiality with respect to her HIV status, it remains unclear what the result might have been if she had been transgender but not living with HIV. It is certainly not outside the realm of possibility that a future court might read Powell as only extending constitutional privacy protections to transgender individuals who have been diagnosed with HIV or another stigma-carrying condition.

Finally, prevailing on a privacy claim depends on a prisoner's transgender status being actually contained in their medical records. There may be situations in which a prisoner identifies as transgender but has not begun a medical transition and thus has no medical records pertaining to their status. ${ }^{124}$ In the event that this person's identity becomes disclosed against their will, Powell and related cases may not govern.

Other privacy cases provide insight into how courts treat issues related to transgender prisoners. When cisgender prisoners, for example, raise privacy concerns in response to officials' decisions to house trans prisoners near them, their claims under the right to

\footnotetext{
${ }^{121}$ Powell, 175 F.3d at 113.

${ }^{122} I d$.

${ }^{123} \mathrm{Id}$. at 109.

${ }^{124}$ Some individuals may not receive a formal diagnosis from a healthcare provider even though they know they are transgender. Others may not begin a medical transition because of financial, insurance-related, or other concerns, or because they simply do not wish to change their physical bodies. See infra note 178 and accompanying text.
} 
privacy may fail. ${ }^{125}$ Crosby v. Reynolds ${ }^{126}$ was the first case in which a prisoner invoked the right to privacy with regard to another prisoner who was transgender. ${ }^{127}$ There, Cheyenne Lamson - a trans woman who had not undergone gender-affirming surgeryhad been placed in a cellblock with other women while detained pretrial. The decision to house Cheyenne with women had been made at her request, after a physician "approved of [the] housing situation from a medical standpoint." ${ }^{28}$ The physician had initially recommended that she be housed separately from the male and female populations, and specifically did not want her living with men "because of both the physical and psychological harm that [she] would likely suffer." 129 Juanita Crosby, a cisgender woman housed in the same cellblock, later sued prison officials, claiming that they had violated her right to privacy by forcing her to live with a transgender woman. ${ }^{130}$ The court granted the prison officials' motion for summary judgment, finding that they were entitled to qualified immunity as "reasonable officials in their shoes would not understand that what they were doing violated the constitutional rights of the plaintiff." 131

Other courts have also been "generous" towards privacy claims by women prisoners. ${ }^{132}$ And while Juanita's claim was dismissed, the Crosby decision presents some unfavorable implications for trans prisoners today. First, because the case did not survive the summary judgment stage due to qualified immunity, the court never addressed whether Juanita's privacy claim had merit. Second, cases in which the right to privacy is used offensively against trans people by others who are incarcerated with them indicate little about the right's applicability to cases brought by trans plaintiffs. Finally, the language of the Crosby opinion suggests that the court, the physician, and even the prison officials themselves held unexpectedly progressive views on trans prisoners, especially

\footnotetext{
${ }^{125}$ Privacy claims in suits challenging gender-inclusive bathroom policies in educational settings also often fail. See infra note 268 and accompanying text.

${ }^{126}$ Crosby v. Reynolds, 763 F. Supp. 666 (D. Me. 1991).

${ }^{127} \mathrm{Id}$. at 669 ("I have found no decision setting forth the privacy rights of prisoners vis-a-vis other prisoners who are transsexual.”).

${ }^{128} I d$. at 667.

${ }^{129} I d$.

${ }^{130} I d$. at 669.

${ }^{131} I d$. at 670.

132 Peek, supra note 33, at 1243.
} 
for the early nineties. Even nearly thirty years later, we cannot expect prison officials to respect trans individuals' requests when it comes to housing or to understand the full extent of the safety concerns arising from housing prisoners incongruously with their gender identity.

\section{Equal Protection}

Another possible approach is to litigate claims under the Equal Protection Clause of the Fourteenth Amendment. The clause prohibits any state from "deny[ing] any person within its jurisdiction the equal protection of the laws." ${ }^{133}$ Although the Equal Protection Clause is contained in the Fourteenth Amendment, the Court has recognized an analogous equal protection component within the Due Process Clause of the Fifth Amendment, ${ }^{134}$ thus extending the right to protect against actions by the federal government.

Some federal courts have held that equal protection claims based on transgender identity are tantamount to claims based on sex. ${ }^{135}$ To prevail on a sex-based equal protection challenge, a plaintiff must show the challenged action fails intermediate scrutiny. ${ }^{136}$ That is, the challenged regulation or policy must not be substantially related to an important state interest. ${ }^{137}$ Other courts have considered trans plaintiffs' claims as distinct from claims based on sex. Still, these courts have held that transgender people are "at least" a quasi-suspect class, warranting intermediate scrutiny. ${ }^{138}$

Under some rare circumstances, trans prisoners have found success in the Equal Protection Clause. The plaintiff in Norsworthy v. Beard, for example, survived a motion

\footnotetext{
${ }^{133}$ U.S. CONST. amend. XIV, $\S 1$.

${ }^{134}$ United States v. Windsor, 570 U.S. 744, 774 (2013).

${ }^{135}$ Norsworthy v. Beard, 87 F. Supp. 3d 1104, 1119 (N.D. Cal. 2015); SmithKline Beecham Corp. v. Abbott Lab'ys, 740 F.3d 471, 481 (9th Cir. 2014) (holding that Windsor "requires that heightened scrutiny be applied to equal protection claims involving sexual orientation"); Doe v. Mass. Dep't of Corr., No. 17-12255, 2018 U.S. Dist. LEXIS 99925, at *24 (D. Mass. June 14, 2018) ("[W] here a State creates a classification based on transgender status, the classification is tantamount to discrimination based on sex.").
}

${ }^{136}$ Craig v. Boren, 429 U.S. 190, 197 (1976).

${ }^{137} I d$.

${ }^{138}$ Doe 1 v. Trump, 275 F. Supp. 3d 167, 208-10 (D.D.C. 2017); see also Olive v. Harrington, No. 15-cv01276 (PC), 2016 U.S. Dist. LEXIS 125128, at*13 (E.D. Cal. Sept. 14, 2016). 
to dismiss her equal protection claim based on prison officials' denial of her requests for gender-affirming surgery and a legal name change. ${ }^{139}$ But Norsworthy is an outlier. Similar claims rarely make it past the pre-trial stage, ${ }^{140}$ and trans prisoners must surmount challenging legal hurdles for successful claims under the Equal Protection Clause.

Individuals bringing equal protection claims under Section 1983 must show that "the defendants acted with an intent or purpose to discriminate" against them. ${ }^{141}$ This element, coupled with a required showing that similarly situated persons outside the protected class were treated differently, is often too much for trans prisoners to overcome. Though Meriwether v. Faulkner primarily concerned an Eighth Amendment claim, the plaintiff, Lavarita Meriwether, had also raised an equal protection argument at the district court level. ${ }^{142}$ In a footnote, the Seventh Circuit pointed out that precedent prevented a prisoner from bringing any equal protection claim unless "state officials had purposefully and intentionally discriminated against" them. ${ }^{143}$ The court decided that Lavarita had not shown that the defendants had any purpose or intent to discriminate against her. ${ }^{144}$

Courts have not grown more sympathetic to trans prisoners' equal protection claims in the three decades since Meriwether was decided. In March 2019, the trans plaintiff's equal protection claim in B. Braxton/Obed-Edom v. City of New York was dismissed by the Southern District of New York for failure to "allege any facts regarding similarly situated inmates who were treated differently." ${ }^{145}$ And in January 2020, the Western District of Texas rejected two other such claims on similar grounds. ${ }^{146}$

\footnotetext{
${ }^{139}$ Norsworthy, 87 F. Supp. 3d at 1120-21.

${ }^{140}$ See, e.g., B. Braxton/Obed-Edom v. City of New York, 368 F. Supp. 3d 729, 740 (S.D.N.Y. 2019); Armstrong v. Mid-Level Practitioner John B. Connally Unit, No. SA-18-CV-00677, 2020 WL 230887, at *78 (W.D. Tex. Jan. 15, 2020).

${ }^{141}$ Norsworthy, 87 F. Supp. 3d at 1118 (quoting Furnace v. Sullivan, 705 F.3d 1021, 1030 (9th Cir. 2013)).

${ }^{142}$ Meriwether v. Faulkner, 821 F.2d 408, 415 n.7 (7th Cir. 1987).

${ }^{143}$ Id. (quoting Shango v. Jurich, 681 F.2d 1091 (7th Cir. 1982)).

${ }^{144} I d$.

${ }^{145}$ B. Braxton/Obed-Edom, 368 F. Supp. 3d at 740.

${ }^{146}$ Armstrong v. Mid-Level Practitioner John B. Connally Unit, No. SA-18-CV-00677, 2020 WL 230887, at *7-8 (W.D. Tex. Jan. 15, 2020).
} 
Another potentially significant problem with relying on equal protection jurisprudence to expand protections for transgender prisoners is the current makeup of the Supreme Court and judicial philosophy of its more conservative members. The recent confirmation of Amy Coney Barrett to replace the late Justice Ruth Bader Ginsburg "alarmed" gender justice advocates, who fear the Court may be ready to roll back LGBTQ+ legal protections. ${ }^{147}$ And while the Court has expanded such protections in the past few decades in decisions including Lawrence v. Texas, ${ }^{148}$ Obergefell v. Hodges, ${ }^{149}$ and Bostock v. Clayton County, ${ }^{150}$ these decisions do not necessarily mean the Justices are ready to extend them into the equal protection realm.

Last term, the Court considered the case of Aimee Stephens, who had been fired from her job at a funeral home after coming out as transgender at work. ${ }^{151}$ In a surprise ruling, Chief Justice Roberts and Justice Gorsuch joined the Court's liberal wing in affirming the Sixth Circuit's decision that discrimination in the workplace based on transgender (or homosexual) status constitutes unlawful discrimination on the basis of sex, violating Title VII of the Civil Rights Act of $1964 .{ }^{152}$ The Bostock decision was a landmark ruling for trans rights and those of the LGBTQ+ community as a whole. In addition to its symbolic significance, it tangibly changed the law in more than twenty-five states where it had

\footnotetext{
${ }^{147}$ Robert Barnes, Barrett's Evasiveness Alarms LGBTQ Advocates Fearful Supreme Court May Roll Back Protections, WASH. Post (Oct. 24, 2020), https://www.washingtonpost.com/politics/courts_law/amy-coneybarrett-gay-rights/2020/10/24/55064586-153b-11eb-ba42-ec6a580836ed_story.html [https://perma.cc/7UT82WSG] (noting that Justice Barrett declined at her Senate confirmation hearing to answer whether she believed Obergefell v. Hodges and Lawrence v. Texas were correctly decided, "sidestepped questions about preserving LGBTQ nondiscrimination protections," and "refused to denounce prior writings and statements that, if implemented through the court, could result in a systematic regression of LGBTQ rights").
}

148539 U.S. 558 (2003).

149576 U.S. 644 (2015).

150140 S. Ct. 1731 (2020).

${ }^{151} I d$.; Adam Liptak \& Jeremy W. Peters, Supreme Court Considers Whether Civil Rights Act Protects L.G.B.T. Workers, N.Y. TimeS (Oct. 8, 2019), https://www.nytimes.com/2019/10/08/us/politics/supremecourt-gay-transgender.html [https://perma.cc/RX9P-5EHJ].

152 Bostock, 140 S. Ct. at 1737; Equal Emp. Opportunity Comm'n v. R.G. \& G.R. Harris Funeral Homes, Inc., 884 F.3d 560, 600 (6th Cir. 2018). Justice Gorsuch's vote was surprising, in part, because he had expressed concern during oral arguments about the "massive social upheaval" that might result from a ruling in favor of Aimee. Liptak \& Peters, supra note 151. 
been legal to fire an employee based on their sexual orientation or transgender status. ${ }^{153}$ Its impact could also extend beyond the employment sphere: The ACLU attorneys who represented Aimee Stephens explained that the decision could affect other Trump administration efforts to deny services to Americans on the basis of gender identity, including under the Fair Housing Act and the Affordable Care Act. ${ }^{154}$

In his dissent, Justice Alito expressed a specific concern that the decision could carry over into equal protection territory: "By equating discrimination because of sexual orientation or gender identity with discrimination because of sex, the Court's decision will be cited as a ground for subjecting all three forms of discrimination to [heightened scrutiny]. ${ }^{" 155}$ But Alito's worry may be overblown, and it remains to be seen how the Court might grapple with an equal protection claim alleging discriminatory treatment based on gender identity. Importantly, the Civil Rights Act is not the Constitution, and courts use different legal standards to interpret and apply them. Although jurists have sometimes considered Title VII's protections to be an extension of the Equal Protection Clause's prohibition against discrimination "from the public to the private sphere," scholars have cautioned against conflating the statutory and constitutional standards. ${ }^{157}$

Justice Kavanaugh's own dissent challenged the majority's legal reasoning, noting that the Court had "never suggested that sexual orientation discrimination is just a form of sex discrimination." 158 It would have been "far easier," he posited, for the Court to have decided that discrimination on the basis of sexual orientation is a form of sex

\footnotetext{
${ }^{153}$ Adam Liptak, Civil Rights Law Protects Gay and Transgender Workers, Supreme Court Rules, N.Y. TiMES (June 15, 2020), https://www.nytimes.com/2020/06/15/us/gay-transgender-workers-supremecourt.html [https://perma.cc/BP9B-M5UN].

${ }^{154}$ David Cole \& Ria Tabacco Mar, The Court Just Teed Up LGBTQ Protections for So Much More than Employment, WASH. Post (June 18, 2020), https://www.washingtonpost.com/opinions/the-court-just-teed-uplgbtq-protections-for-so-much-more-than-employment/2020/06/18/725f7832-b0dc-11ea-8f5663f38c990077_story.html [https://perma.cc/3ZWX-TYTA].

${ }^{155}$ Bostock, 140 S. Ct. at 1783 (Alito, J., dissenting).

${ }^{156}$ See Cheryl I. Harris, Limiting Equality: The Divergence and Convergence of Title VII and Equal Protection, 2014 U. ChI. Legal F. 95, 99-100 (2014).

${ }^{157}$ See, e.g., Mary E. Westby, Taxman v. Board of Education: The Conflation of Equal Protection and Title VII Standards in Affirmative Action, 1998 UTAH L. REV. 331, 361-62 (1998).

${ }^{158}$ Bostock, 140 S. Ct. at 1832-33 (Kavanaugh, J., dissenting).
} 
discrimination in certain earlier cases than it was in Bostock. ${ }^{159}$ Kavanaugh may have erroneously conflated the two standards in his dissent, but he is right about one thing: The Court has yet to decide whether the Equal Protection Clause covers classifications based on transgender status. Considering also that the bar to prevail on a constitutional claim is generally higher than it is for a Title VII claim, ${ }^{160}$ it would be a mistake-a potentially dangerous one for plaintiffs - to presume that the Court would see Bostock as a reason to look favorably upon an equal protection claim by a transgender litigant.

\section{State Law Claims}

Although this Note focuses on federal law, it is worth noting that trans prisoners have successfully brought state tort and constitutional claims, though these claims are comparatively quite rare. For example, one trans plaintiff's motion for a housing transfer was granted under a Connecticut nondiscrimination statute. ${ }^{161}$ State law, however, is not always favorable to trans prisoners. The plaintiff in Giraldo v. Department of Corrections $\&$ Rehabilitation ${ }^{162}$ could not sustain a claim for damages under a provision ${ }^{163}$ of the California Constitution that is the state's analogue of the Federal Eighth Amendment. ${ }^{164}$ Another trans individual petitioned for a writ of mandamus to compel the State of

\footnotetext{
${ }^{159}$ Id. Justice Kavanaugh specifically cited Bowers v. Hardwick, 478 U.S. 186 (1986) (upholding a state law criminalizing sodomy); Romer v. Evans, 517 U.S. 620 (1996) (applying rational basis review in deciding a state amendment prohibiting anti-discrimination protections for homosexual persons violated the Equal Protection Clause); Lawrence v. Texas, 539 U.S. 558 (2003) (overruling Bowers and holding a state sodomy criminalization law was unconstitutional); United States v. Windsor, 570 U.S. 744 (2013) (holding that the definition of marriage contained in Section 3 of the Defense of Marriage Act, which prevented federal recognition of same-sex marriages, violated the Due Process Clause); and Obergefell v. Hodges, 576 U.S. 644 (2015) (concluding that the Fourteenth Amendment protects the fundamental right to marry a person of the same sex), as moments when the Court could have clarified the breadth of sex discrimination but did not.

${ }^{160}$ Westby, supra note 157 , at $361-62$.

${ }^{161}$ In re Doe, No. F04JV32912660A, 2014 Conn. Super. LEXIS 1128, at*37 (Super. Ct. May 6, 2014).

${ }^{162}$ Giraldo v. Dep’t of Corr. \& Rehab., 168 Cal. App. 4th 231 (Cal. Ct. App. 2008).

${ }^{163}$ CAL. Const. art. I, $\S 17$ (“Cruel or unusual punishment may not be inflicted or excessive fines imposed.”).

${ }^{164}$ Giraldo, 168 Cal. App. 4th at 256.
} 
Delaware to transfer her to a women's facility. ${ }^{165}$ Her petition was dismissed and the state supreme court summarily affirmed. ${ }^{166}$

\section{Moving Forward: Considerations for an Inclusive Framework}

Beyond the troubles with the existing claims discussed above, other problems prevent portions of the trans community from accessing legal remedies. This section discusses the problematic ramifications of relying on a plaintiff's "legal" gender, gender expression, and biological characteristics. ${ }^{167}$ A new framework, such as the one proposed in Part III, should take these issues into account to be appropriately inclusive.

\section{1. "Legal" Gender}

When trans prisoners do prevail under the law, negative implications can accompany their victories. Consider Shaw v. District of Columbia. The plaintiff, Patti Shaw, challenged Washington, D.C., officials' decision to detain her with men in three separate instances. ${ }^{168}$ Among other claims, she challenged the conditions of her confinement as a pre-trial detainee under the Fifth Amendment's Due Process Clause, rather than the Eighth Amendment. ${ }^{169}$ The district court ruled that the defendants acted with deliberate indifference to Patti's safety while she was in detention: "[A] reasonable officer would know that treating a female detainee as plaintiff was treated (i.e., holding her with male detainees and otherwise treating her as if she were male) exposed her to a substantial risk of serious harm, and, therefore, would know that those actions violated her constitutional rights." 170

${ }^{165}$ Winter v. Del. Dep’t of Just., 210 A.3d 733 (Del. 2019).

${ }^{166} \mathrm{Id}$.

${ }^{167}$ As with the legal claims discussed supra in Parts II.A and II.B, the issues raised in this section are not necessarily exhaustive.

${ }^{168}$ Shaw v. District of Columbia, 944 F. Supp. 2d 43, 48 (D.D.C. 2013).

${ }^{169} \mathrm{Id}$. at 57 . The legal standard for Fifth Amendment due process claims by pre-trial detainees is the same as that for Eighth Amendment claims by convicted individuals. See id. ("[A] pretrial detainee's rights are violated if she is 'incarcerated under conditions posing a substantial risk of serious harm' and the detaining official's 'state of mind is one of deliberate indifference to inmate health or safety." (quoting Farmer v. Brennan, 511 U.S. 825, 834 (1994)) (citation omitted) (internal quotation marks omitted)).

${ }^{170} I d$. at 59. 
On its face, Shaw appears to be a favorable development. The danger of the 2013 opinion lies in the district court's reliance on outdated ideas of sex and gender in highlighting the "significance" of the fact that the plaintiff was "legally a female."171 Patti had undergone gender-affirming surgery and had changed her gender marker on her driver's license prior to all three arrests. ${ }^{172}$ If Patti had not yet made these changes, it is likely - if not certain, given the language used by the court - that she would have lost her case. Litigants' entitlement to relief under the Constitution should not be contingent on their having undergone "legal" gender changes. One problem with such a requirement is that it unfairly disadvantages trans individuals who cannot obtain name or gender marker changes under the law because of socioeconomic or educational background, disability, immigration status, or some other characteristic, perpetuating already-ingrained classism within the nation's legal and criminal justice systems. Gender identity is distinct from both biological sex and "legal" markers like driver's license designations and names, ${ }^{173}$ it should remain so under the law in the interests of inclusivity and respect.

\section{Gender Expression and Biological Characteristics}

Just as official markers of gender are not necessarily indicative of a person's true self, gender is not always visible in the ways we might expect based on social constructs. The fact that a person identifies as a woman, for example, does not necessarily mean she chooses to express her gender in a traditionally "feminine" manner. But despite new understandings of gender as distinct from sex assigned at birth, and of conceptions of gender as socially constructed, the law has yet to catch up.

Notably, failure to conform with societal expectations of gender may be detrimental to trans plaintiffs under current law. Courts have responded favorably to plaintiffs who exhibit traditional expressions of gender. In Farmer, the Court repeatedly noted the

\footnotetext{
${ }^{171} I d$. at 58 .

${ }^{172} I d$. at 48 .

173 The distinction between gender and sex is widely accepted by the general public, including medical professionals and popular media. See, e.g., Jennifer Tseng, Sex, Gender, and Why the Differences Matter, 10 Virtual Mentor 427 (2008); Kristen Rogers, Gender Identity: The Difference Between Gender, Sex and Other Need-to-Knows, CNN (June 10, 2020), https://www.cnn.com/2020/06/10/health/gender-identityexplainer-wellness/index.html [https://perma.cc/J7W3-XWXJ]. Some federal and state courts have also begun to come around to this modern understanding. See, e.g., DeJohn v. Temple Univ., 537 F.3d 301, 318 n.20 (3d Cir. 2008) ("The term 'gender' has recently acquired a meaning distinct from 'sex."'); Parents for Priv. v. Dall. Sch. Dist. No. 2, 326 F. Supp. 3d 1075, 1083 (D. Or. 2018); Commonwealth v. Smith, 879 N.E.2d 87, 97 n.6 (Mass. 2008); McGrath v. Toys “R” Us, Inc., 3 N.Y.3d 421, 435 n.4 (2004).
} 
plaintiff's "overtly feminine characteristics," 174 a fact on which the plaintiff had relied in arguing that the defendants were "deliberately indifferent to his [sic] safety." 175 That the plaintiff appeared feminine meant they were at greater risk of assault, and they argued the defendants should have known of this greater risk based on their feminine gender expression. ${ }^{176}$ Similarly, the Seventh Circuit in Meriwether noted the plaintiff's feminine "body shape" and the fact that she wore makeup and bras in the first few paragraphs of the opinion. ${ }^{177}$ For trans plaintiffs, relying on the Eighth Amendment to challenge unjust conditions of their incarceration thus involves relying on outdated conceptions of what gender is and should be.

Under a better framework, gender expression or traditionally gendered characteristics would not play a role in legal analysis. A person should not have a worse chance of prevailing on their constitutional challenge just because they do not conform to societal expectations of gender. This holds true for other gender expectations - namely, those pertaining to anatomy. Many trans people elect to receive gender-affirming surgeries, but many do not. ${ }^{178}$ Other trans prisoners would like to undergo surgery in the future but did not do so before being incarcerated. An effective legal framework should respect all gender identities, regardless of where a person is in their transition.

\section{Articulating, Advocating for, and Defending the Right to Live Freely}

As the above discussion makes clear, transgender prisoners remain vulnerable to mistreatment under the current state of the law. This Part proposes a reframing of substantive due process that may feasibly help trans prisoners - and trans people generally-vindicate their constitutional rights and gain much-needed protection from state and federal governments: Attorneys should advocate for and judges should recognize a right to live freely according to one's gender identity. This Part first sketches a rough history of substantive due process jurisprudence, from Lochner to Obergefell. It

\footnotetext{
${ }^{174}$ Farmer, 511 U.S. at 852 (Blackmun, J., concurring).

${ }^{175} \mathrm{Id}$. at 831-32 (“A transsexual who 'projects feminine characteristics,' would be particularly vulnerable to sexual attack.”).

${ }^{176} I d$.

${ }^{177}$ Meriwether v. Faulkner, 821 F.2d 408, 410 (7th Cir. 1987).

${ }^{178}$ Trans individuals may elect not to or may not have the ability to receive surgery for any number of reasons, such as socioeconomic status or a lack of access to health insurance. Others may decline surgical procedures because they would not meaningfully change their level of comfort or ability to live freely as their truest self. See also supra text accompanying note 173.
} 
then argues for a progressive interpretation of the Due Process Clause that would define the right to live freely as fundamental. Next, it illustrates, non-exhaustively, the contexts in which the right to live freely might be beneficial for trans people who have experienced a deprivation of rights. It then considers some counterarguments and explains why, even if containing some merit, they do not wholly undermine the right to live freely as a useful alternative to other constitutional claims. Lastly, it reminds us to situate any interim progress such as the one this Note proposes in the context of the eventual goals of the prison abolition movement.

\section{A. Traditional Substantive Applications of the Due Process Clause}

The Fourteenth Amendment holds that "[n]o State shall . . . deprive any person of life, liberty, or property, without due process of law." Process Clause includes substantive, as well as procedural, protections against government action. ${ }^{180}$ Perhaps the most well-known application of the Due Process Clause, in recent decades, is its protection of the right to privacy. The modern right to privacy emerged in Griswold v. Connecticut, ${ }^{181}$ in which the Court held that a state law banning the use of contraceptives by married couples violated the Bill of Rights. The Court later grounded the right in the Due Process Clause of the Fourteenth Amendment. ${ }^{182}$ Today, the right to privacy protects, inter alia, the fundamental right to an abortion ${ }^{183}$ and the fundamental right to marry a person of the same sex. ${ }^{184}$

Although modern applications of substantive due process often fall into the privacy category, ${ }^{185}$ there are multiple types of government action raising colorable claims as a

\footnotetext{
${ }^{179}$ U.S. ConST. amend. XIV, § 1; see also U.S. Const. amend. V (conferring the same protections against federal action). Because the large majority of prisoners reside in state prisons, see BRONSON \& CARSON, supra note 48, at 3, most due process claims by prisoners are brought under the Fourteenth Amendment.

${ }^{180}$ See Planned Parenthood of Se. Pa. v. Casey, 505 U.S. 833, 846-47 (1992).

181381 U.S. 479 (1965).

${ }^{182}$ See Roe v. Wade, 410 U.S. 113, 153 (1973).

${ }^{183} \mathrm{Id}$.

${ }^{184}$ Obergefell v. Hodges, 135 S. Ct. 2584, 2599 (2015).

${ }^{185}$ See, e.g., Lawrence v. Texas, 539 U.S. 558 (2003) (deciding that laws prohibiting private homosexual activity violate the Due Process Clause); Roe, 410 U.S. 113 (holding that abortion restrictions implicate a constitutional right to privacy).
} 
result of a deprivation of life, liberty, or property. ${ }^{186}$ For example, during the early twentieth century, the Court used substantive due process to invalidate certain economic regulations; in the controversial Lochner v. New York ${ }^{187}$ the Court held that a state law limiting working hours for bakers violated the Due Process Clause of the Fourteenth Amendment. ${ }^{188}$ The Court later applied the doctrine to protect fundamental individual rights such as freedom of religion and freedom of speech. ${ }^{189}$ Courts have also invoked substantive due process in cases involving excessive force by law enforcement officials or school personnel, ${ }^{190}$ patients in mental institutions, ${ }^{191}$ and certain academic decisions ${ }^{192}$ among other contexts.

Prisoners have relied on substantive due process doctrine in claims alleging excessive force by prison officials, ${ }^{193}$ although in recent decades the Eighth Amendment has been

\footnotetext{
${ }^{186}$ Michael J. Phillips, The Nonprivacy Applications of Substantive Due Process, 21 RUTGERs L.J. 537, 543 (1990).
}

187198 U.S. 45 (1905).

${ }^{188}$ Id. Lochner was famously overruled by West Coast Hotel Co. v. Parrish, 300 U.S. 379 (1937), in which the Court upheld the denial of a due process challenge to a minimum wage law for women.

${ }^{189}$ See William L. Want, Economic Substantive Due Process: Considered Dead Is Being Revived by a Series of Supreme Court Land-Use Cases, 36 U. Haw. L. Rev. 455, 477-78 (2014); see, e.g., United States v. Carolene Products Co., 304 U.S. 144, 152-53 (1938).

${ }^{190}$ See, e.g., Rochin v. California, 342 U.S. 165, 172 (1952) (overruling a conviction based on evidence obtained through excessive force that "shock[ed] the conscience"); Metzger v. Osbeck, 841 F.2d 518 (3d Cir. 1988); Rinker v. Napa Cnty., 831 F.2d 829 (9th Cir. 1987); Webb v. McCullough, 828 F.2d 1151 (6th Cir. 1987); Garcia v. Miera, 817 F.2d 650 (10th Cir. 1987); Gilmere v. City of Atlanta, 774 F.2d 1495 (11th Cir. 1985); Hall v. Tawney, 621 F.2d 607 (4th Cir. 1980); see also Phillips, supra note 186, at 549-55. But see Woodard v. Los Fresnos Indep. Sch. Dist., 732 F.2d 1243 (5th Cir. 1984) (rejecting substantive due process liability for the administration of three swats by a school bus driver after a student's use of abusive language).

${ }^{191}$ See, e.g., Youngberg v. Romeo, 457 U.S. 307 (1982) (holding that a mental patient had Fourteenth Amendment liberty interests in safe conditions of confinement, freedom from bodily restraints, and reasonable training if required by these two interests); see also Phillips, supra note 186, at 559-61. But see Buthy v. N.Y. Comm'r of Off. of Mental Health, 818 F.2d 1046, 1050-51 (2d Cir. 1987) (upholding a rule that all patients must be awake for the same sixteen-hour period as a mere de minimis infringement of liberty unworthy of due process concerns).

192 See Phillips, supra note 186, at 561-62.

${ }^{193}$ See, e.g., Johnson v. Glick, 481 F.2d 1028, 1029 (2d Cir. 1973) (reversing a summary judgment motion against a prisoner alleging excessive force by an officer and concluding the prisoner had stated a due process claim). 
used more frequently. ${ }^{194}$ Beyond the excessive force context, prisoners may raise substantive due process claims for mistreatment that does not implicate another provision of the Constitution. ${ }^{195}$ Notably, the Turner ${ }^{196}$ Court struck down a state law prohibiting prisoners from marrying without the permission of the prison superintendent. ${ }^{197}$ Although the opinion never discussed substantive due process - or any constitutional provisionexplicitly, the language sounds "unmistakably" like substantive due process analysis. ${ }^{198}$ The Court later applied the Turner standard in Washington v. Harper, ${ }^{199}$ describing the claim as partially a substantive due process question. ${ }^{200}$ And because the Eighth Amendment does not apply to people who have not been convicted and sentenced, pretrial detainees hold additional rights under the Due Process Clause of the Fifth and Fourteenth Amendments that would otherwise fall under the purview of the Eighth Amendment. ${ }^{201}$

As is evident from its continually evolving interpretive history, the scope of substantive due process is not fixed. The Court has emphasized as much for decades: "To believe that this judicial exercise of judgment could be avoided by freezing 'due process of law' at some fixed stage of time or thought is to suggest that the most important aspect

\footnotetext{
${ }^{194}$ See Phillips, supra note 186, at 555-56.

${ }^{195}$ Id. at 556; see, e.g., Ellard v. Ala. Bd. of Pardons \& Paroles, 824 F.2d 937 (11th Cir. 1987) (concluding that substantive due process applies to a state's decision to void a previous parole grant, but such a decision is permissible where the parole was issued following a clear departure from statutory and regulatory guidelines that substantially undermined the determination of whether the state's penological interests would be served by continued incarceration); Morello v. James, 810 F.2d 344 (2d Cir. 1987) (holding that the substantive due process right of access to the courts means, inter alia, that a state cannot take the legal work product of a convicted prisoner making a pro se appeal); Gilson v. Cox, 711 F. Supp. 354 (E.D. Mich. 1989) (deciding that a male prisoner's substantive due process claim for sexual advances and groping by female corrections officer could withstand a motion for summary judgment).
}

196482 U.S. 78 (1987).

${ }^{197}$ Richard S. Myers, The End of Substantive Due Process?, 45 WASH. \& LeE L. Rev. 557, 583-84 (1988).

${ }^{198} I d$. at $583 \mathrm{n} .165$ (referring to the Court's discussion of a "right to marry"). The respondents' brief also explicitly invoked due process. See Brief for Respondents at 59, Turner, 482 U.S. 78 (No. 85-1384).

199494 U.S. 210 (1990).

${ }^{200}$ Phillips, supra note 186, at 556 n.97.

${ }^{201} I d$. at 557. Pretrial detainees hold, for example, a substantive due process right to proper medical treatment. Id.; see, e.g., Williams-El v. Johnson, 872 F.2d 224, 230-31 (8th Cir. 1989) (adopting a standard of "deliberate indifferen[ce] to [the plaintiff"s] serious medical needs" (emphasis omitted)). 
of constitutional adjudication is a function for inanimate machines and not for judges." Nor does the Constitution as a whole dictate the "outer limits" of the range of liberties it protects. ${ }^{203}$ As the second Justice Harlan recognized:

[T] he full scope of the liberty guaranteed by the Due Process Clause cannot be found in or limited by the precise terms of the specific guarantees elsewhere provided in the Constitution. This 'liberty' is not a series of isolated points pricked out .... It is a rational continuum which, broadly speaking, includes a freedom from all substantial arbitrary impositions and purposeless restraints, ... and which also recognizes, what a reasonable and sensitive judgment must, that certain interests require particularly careful scrutiny of the state needs asserted to justify their abridgment. ${ }^{204}$

The freedoms protected by the Due Process Clause are broad and not bound by a purely textual interpretation. Just as Justices Frankfurter, Harlan, and-famously-Brennan ${ }^{205}$ understood the Constitution to be a living document, jurists today should recognize the need for stronger constitutional protections for the transgender community, including its incarcerated members.

\section{B. Applying Substantive Due Process to Protect All Gender Identities}

Recognizing that the Constitution allows for a greater understanding of the rights it protects, we may now apply the substantive Due Process Clause to our newer understanding of identity. Trans prisoners and their advocates should consider articulating a right to live freely according to one's gender identity when challenging actions by prison officials that deprive the prisoner of a meaningful ability to live in line

\footnotetext{
${ }^{202}$ Rochin v. California, 342 U.S. 165, 171-72 (1952) (Frankfurter, J.).

${ }^{203}$ Planned Parenthood of Se. Pa. v. Casey, 505 U.S. 833, 848-49 (1992) ("Neither the Bill of Rights nor the specific practices of States at the time of the adoption of the Fourteenth Amendment marks the outer limits of the substantive sphere of liberty which the Fourteenth Amendment protects.").
}

${ }^{204}$ Poe v. Ullman, 367 U.S. 497, 543 (1961) (Harlan, J., dissenting) (dissenting from dismissal on jurisdictional grounds).

${ }^{205}$ William J. Brennan, Jr., Assoc. Just., Sup. Ct. of the U.S., The Constitution of the United States: Contemporary Ratification, Address at the Georgetown University Symposium: Text and Teaching (Oct. 12, 1985) (" $[T]$ he genius of the Constitution rests not in any static meaning it might have had in a world that is dead and gone, but in the adaptability of its great principles to cope with current problems and current needs."). 
with their true self. This section considers what such a right protects, argues that it should be considered a fundamental right, and explains that violations of the right should not withstand even the strictest judicial review.

\section{The Due Process Clause Guarantees the Right to Live Freely According to One's Gender Identity}

It is impossible to define the right to live freely with anything close to accuracy. Indeed, what it looks like to live true to oneself depends wholly on the person exercising the right. And yet the concept remains rather simple: Can someone live freely if they are assumed to be something they are not? When a trans woman is considered to be a man, by the government no less, can we ever say she is living freely as herself? Although previous Courts may not have conceptualized the right to live freely in the context of gender identity, the Justices understood that within the Constitution lies the right to decide how to be: "At the heart of liberty is the right to define one's own concept of existence, of meaning, of the universe, and of the mystery of human life. Beliefs about these matters could not define the attributes of personhood were they formed under compulsion of the State." ${ }^{206}$ As this section argues, the right to live freely described above is a fundamental liberty contained within a modern understanding of the Due Process Clause, and trans prisoners should consider employing the doctrine to vindicate their constitutional right to live according to their identity while incarcerated.

Courts have identified two "threads" of substantive due process jurisprudence, one dealing with "legislative" deprivations of rights and the other with "non-legislative" actions. ${ }^{207}$ Actions by prison officials will generally be non-legislative, although it is not inconceivable that a trans individual might seek to challenge a particular statute or a "broad executive regulation" that violates substantive due process rights. ${ }^{208}$ Legislative actions generally must pass the rational basis test, although certain acts burdening "fundamental rights" may be subject to stricter scrutiny. ${ }^{209}$ Actions that infringe upon fundamental rights survive judicial review only if they are "narrowly tailored to serve a

\footnotetext{
${ }^{206}$ Casey, 505 U.S. at 851.

${ }^{207}$ Nicholas v. Pa. State Univ., 227 F.3d 133, 139 (3d Cir. 2000).

${ }^{208}$ Non-legislative acts include "executive acts, such as employment decisions, [which] typically apply to one person or to a limited number of persons, while legislative acts, generally laws and broad executive regulations, apply to large segments of society." Id. at 139 n.1 (quoting Homar v. Gilbert, 89 F.3d 1009, 1027 (3d Cir. 1995) (Alito, J., concurring in part and dissenting in part)).
}

${ }^{209}$ Id. (quoting Alexander v. Whitman, 114 F.3d 1392, 1403 (3d Cir. 1997)). 
compelling state interest." ${ }^{\prime 210}$ Similarly, an inquiry into whether the substantive due process clause protects a certain right against non-legislative action "depends on whether that interest is 'fundamental' under the United States Constitution." 111 The Due Process Clause protects individuals from any "arbitrary or irrational deprivation" of fundamental rights. ${ }^{212}$

\section{The Right to Live Freely is Fundamental}

There is no clear test or standard for determining what constitutes a fundamental right. Instead, judges look to a variety of factors including legal precedent, cultural history, and social norms to piece together a broad, contextual understanding of the interest at stake. Justice Powell famously wrote that fundamental rights are those "deeply rooted in this Nation's history and tradition." ${ }^{213}$ Other justices have maintained that fundamental rights are "'implicit in the concept of ordered liberty,' such that 'neither liberty nor justice would exist if they were sacrificed." ${ }^{214}$ Such rights invoke the ability to make decisions "affecting [one's] destiny." ${ }^{15}$ The application of these enduring principles compels the conclusion that the right to live freely in one's gender is so intrinsic to the human condition, and as such so deeply rooted in the ethos of the United States, that it should be recognized as fundamental by the courts.

Determining whether a right is fundamental involves a full appreciation of "the extent of the liberty at stake." ${ }^{216}$ When the Court in Lawrence v. Texas overturned Bowers v. Hardwick, ${ }^{217}$ which had upheld a state law criminalizing the act of sodomy, the majority noted that the Bowers Court mischaracterized the liberty interest that had been

\footnotetext{
${ }^{210}$ Washington v. Glucksberg, 521 U.S. 702, 720-21 (1997) (quoting Reno v. Flores, 507 U.S. 292, 302 (1993)).

${ }^{211}$ Nicholas, 227 F.3d at 140.

${ }^{212} I d$. at 142.

${ }^{213}$ Moore v. E. Cleveland, 431 U.S. 494, 503 (1977) (plurality opinion).

${ }^{214}$ Glucksberg, 521 U.S. at 721 (Rehnquist, C.J.) (quoting Palko v. Connecticut, 302 U.S. 319, 325, 326 (1937) (Cardozo, J.)).

${ }^{215}$ Lawrence v. Texas, 539 U.S. 558, 565 (2003).

${ }^{216} I d$. at 567.

217478 U.S. 186 (1986).
} 
violated. It was not a right to engage in certain consensual sexual acts, but rather a right against state action attempting to control and define - and, notably, criminalize - the parameters of personal relationships. ${ }^{218}$ The Bowers decision, in defining the right in this way, "demean[ed] the claim" in the same manner as saying marriage is simply about a right to engage in consensual sex. ${ }^{219}$ In a similar vein, recognizing a right to live freely as one's inherent gender is not the same as recognizing a right to undergo gender-affirming surgery (although the latter may be encompassed by the former). Indeed, gender identity and biological sex are not the same thing. ${ }^{20}$ Gender is part of a person's essential identity; the weight of the liberty to express one's gender cannot be overstated.

A longstanding history of respect for a right may be germane to its fundamentality. ${ }^{221}$ So, too, are the laws and cultures of "wider civilization." The Lawrence Court considered that the legal reasoning grounding Bowers had been rejected by other countries and the European Court of Human Rights. ${ }^{222}$ Today, trans prisoners across the world are receiving greater protections. The United Kingdom, for example, recently adopted a policy "under which prisons must ... recognise and respect inmates with fluid and non-

\footnotetext{
${ }^{218}$ Lawrence, 539 U.S. at 567.

${ }^{219} I d$.

${ }^{220}$ Even federal courts define sex and gender differently. One set of definitions used across multiple courts reads:
}

\begin{abstract}
"Sex" is defined as the "anatomical and physiological processes that lead to or denote male or female." Typically, sex is determined at birth based on the appearance of external genitalia.

"Gender" is a "broader societal construct" that encompasses how a "society defines what male or female is within a certain cultural context." A person's gender identity is their subjective, deep-core sense of self as being a particular gender.
\end{abstract}

Parents for Priv. v. Dall. Sch. Dist. No. 2, 326 F. Supp. 3d 1075, 1083 (D. Or. 2018) (quoting Doe v. Boyertown Area Sch. Dist., 893 F.3d 179, 183 (3d Cir. 2018)); see also, e.g., DeJohn v. Temple Univ., 537 F.3d 301, 318 n.20 (3d Cir. 2008). The fact that courts have found discrimination based on sex stereotypes or gender expression to be unlawful sex discrimination under Title VII, see infra note 278 and accompanying text, does not undermine the modern understanding of gender and sex as distinct concepts.

${ }^{221}$ Lawrence, 539 U.S. at 567-71.

${ }^{222} \mathrm{Id}$. at $576-77$. 
binary genders." ${ }^{, 23}$ The policy mandates that officials treat transgender prisoners "according to the gender in which they identify."224 By recognizing the right to live freely, the United States would join a growing global community supporting trans equality.

Even more importantly, emerging social or cultural norms along with scientific advancement may also provide guidance as courts evolve in their deepening understanding of these issues. Justice Kennedy, who authored the majority opinion in Lawrence, noted the growing "recognition" and acceptance of LGBTQ+ rights in reaching the decision to overturn Bowers. ${ }^{225} \mathrm{He}$ quoted one of his earlier opinions stressing the importance of modern ideas in substantive due process analysis: "History and tradition are the starting point but not in all cases the ending point of the substantive due process inquiry." ${ }^{226}$ Later, in Obergefell v. Hodges, the Court considered the institution of marriage as part of the "legal and social order" along with the contemporary urgency of marriage equality together to conclude that same-sex marriage is a fundamental right. ${ }^{227}$

When the Court discussed emerging norms in Lawrence, they were not referring to widespread support for LGBTQ+ rights. The case was decided only eighteen years ago, in 2003, and yet the national climate for gay, lesbian, and bisexual rights was vastly different than it is today. Over the course of that year, support among Americans for same-sex marriage actually decreased, from thirty-nine percent in June to thirty-one

\footnotetext{
${ }^{223}$ Mia Harris, British Prisons Must Now Recognise Gender Fluid and Non-Binary Inmates, Conversation (Nov. 16, 2016), http://theconversation.com/british-prisons-must-now-recognise-gender-fluid-and-nonbinary-inmates-63132 [https://perma.cc/X22C-NSD5].

${ }^{224}$ Ministry of Just., Review on the Care and Management of Transgender Offenders, 2016, at 5 (U.K.).

${ }^{225}$ Lawrence, 539 U.S. at 572.

${ }^{226}$ Id. (quoting Cnty. of Sacramento v. Lewis, 523 U.S. 833, 857 (1998) (Kennedy, J., concurring)). Notably, Justice Kennedy wrote the majority opinions of "four key cases that transformed gay rights in America." Jessica Contrera, Anthony Kennedy and the Four Supreme Court Rulings That Changed Gay Life in America, WASH. POST (June 27, 2018), https://www.washingtonpost.com/lifestyle/style/anthony-kennedy-and-the-foursupreme-court-rulings-that-changed-gay-life-in-america/2018/06/27/fc2a345c-7a48-11e8-80be6d32e182a3bc_story.html [https://perma.cc/MDV8-J6K9]. Now retired, his enduring legacy may well turn out to be his support for LGBTQ+ constitutional rights.
}

${ }^{227}$ See Obergefell v. Hodges, 576 U.S. 644, 670-72 (2015). 
percent in December. ${ }^{228}$ The country was still fifteen years away from recognition of same-sex marriage under the Constitution. ${ }^{229}$ Some justices themselves still adhered to now-outdated notions of what it means to be in a same-sex relationship. Justice Scalia, in a dissenting opinion, attempted to draw a comparison to laws prohibiting bestiality or incest. ${ }^{230}$ Still, a majority found enough cause in both tradition and modern attitudes to expand substantive due process doctrine and afford new protections to the LGBTQ+ community.

It is now time for the Court to recognize the right to live freely as a fundamental right under our Constitution. We find ourselves today in an era of emerging recognition and acceptance of the transgender community. Sixty-two percent of Americans in a recent study said they have become "more supportive" of trans people in the last five years. ${ }^{231}$ Seventy-one percent support laws protecting LGBTQ+ people from discrimination, a number that has remained steady since at least 2015. ${ }^{232}$ In 2016, the Secretary of Defense announced that trans people, who had previously been categorically barred from enlisting in the military, could now serve openly. ${ }^{233}$ Donald Trump's reinstatement of the ban in 2017 was met with robust federal litigation, ${ }^{234}$ Congressional bills and resolutions

${ }^{228}$ Gay and Lesbian Rights, GALLUP, https://news.gallup.com/poll/1651/gay-lesbian-rights.aspx [https://perma.cc/BQ8G-WPZ6]. Support has since more than doubled. Sixty-three percent of survey respondents in May 2019 said they believe same-sex marriages "should be valid" under law. Id.

${ }^{229}$ See Obergefell, 576 U.S. 644 (holding that the Fourteenth Amendment guarantees the fundamental right to marry for same-sex couples).

${ }^{230}$ See Lawrence, 539 U.S. at 590 (Scalia, J., dissenting). Chief Justice Rehnquist and Justice Thomas joined the opinion. Id. at 586.

${ }^{231}$ Daniel Greenberg et al., America's Growing Support for Transgender Rights, PuB. ReLigion Rsch. Inst. (June 11, 2019), https://www.prri.org/research/americas-growing-support-for-transgender-rights/ [https://perma.cc/CKR3-K33V]. Only one ideological group, "Conservative Republicans," reported increased support among less than half of respondents. Still, forty percent of Conservative Republicans said their support for transgender people increased. Id.

${ }^{232} I d$.

${ }^{233}$ Matthew Rosenberg, Transgender People Will Be Allowed to Serve Openly in Military, N.Y. Times (June 30, 2016), https://www.nytimes.com/2016/07/01/us/transgender-military.html [https://perma.cc/JZ3E-DZCJ].

${ }^{234}$ Multiple federal courts issued nationwide preliminary injunctions halting enforcement of the ban on transgender military service. See, e.g., Stone v. Trump, 280 F. Supp. 3d 747, 772 (D. Md. 2017) (granting preliminary injunction); Doe 1 v. Trump, 275 F. Supp. 3d 167, 217 (D.D.C. 2017) (granting in part and denying in part a preliminary injunction); Stockman v. Trump, No. EDCV 17-1799 (KKx), 2017 U.S. Dist. 
rejecting the policy change, ${ }^{235}$ and intense public outrage. Awareness of the plight of trans prisoners has also reached the public consciousness; news outlets reported extensively on Chelsea Manning's experiences while incarcerated, from her two suicide attempts $^{236}$ to her efforts to receive hormone therapy and gender-affirming surgery. ${ }^{237}$ Even the relatively conservative current Supreme Court expanded workplace antidiscrimination protections for trans people in Bostock v. Clayton County. ${ }^{238}$

Americans today are considerably more accepting of transgender people, and aware of their struggles in society, than they were of gay, lesbian, and bisexual people at the time of Lawrence. Trans voices are now amplified in popular culture, ${ }^{239}$ trans athletes win

LEXIS 221323, at*51 (C.D. Cal. Dec. 22, 2017) (granting preliminary injunction); Karnoski v. Trump, No. C17-1297, 2017 U.S. Dist. LEXIS 203481, at *32-33 (W.D. Wash. Dec. 11, 2017) (granting preliminary injunction).

${ }^{235}$ See H.R. 1032, 116th Cong. (2019) ("To provide for the retention and service of transgender individuals in the Armed Forces"); S. 373, 116th Cong. (2019) (same); H.R. Res. 124, 116th Cong. (2019) ("Expressing opposition to banning service in the Armed Forces by openly transgender individuals"). President Joe Biden issued an executive order reversing the ban during his first week in office. Exec. Order No. 14,004, 86 C.F.R. $7471(2021)$.

${ }^{236}$ See, e.g., Savage, Chelsea Manning Sentenced to Solitary Over Suicide Attempt, supra note 39; Savage, Chelsea Manning Tried Committing Suicide a Second Time in October, supra note 39.

${ }^{237}$ See, e.g., Ewan Palmer, Chelsea Manning Tweets Photo from Hospital Bed After Gender Affirmation Surgery, NEwSwEEK (Oct. 22, 2018), https://www.newsweek.com/chelsea-manning-tweets-photo-hospitalbed-after-gender-affirmation-surgery-1180486 [https://perma.cc/YC98-2HCL]; Jonah E. Bromwich, Chelsea Manning Told She Can Have Gender Reassignment Surgery, Lawyer Says, N.Y. TimEs (Sept. 13, 2016), https:/www.nytimes.com/2016/09/14/us/chelsea-manning-told-she-can-have-gender-reassignment-surgerylawyer-says.html [https://perma.cc/K73H-DXZ9]; Eyder Peralta, Military Agrees To Provide Chelsea Manning With Hormone Therapy, NPR (Feb. 12, 2015), https://www.npr.org/sections/thetwoway/2015/02/12/385861106/reports-military-agrees-to-provide-chelsea-manning-with-hormone-therapy [https://perma.cc/S37K-64DW].

238140 S. Ct. 1731 (2020).

${ }^{239}$ See, e.g., Riley Leight, Netflix Ushered In a New Era of Trans Representation on TV. What's Next?, OUTLINE (Dec. 19, 2019), https://theoutline.com/post/8448/netflix-trans-representation-2010s-orange-is-thenew-black?zd=1\&zi=6xuokrqr [https://perma.cc/NY5T-RSEK]. 
gold medals in international sports, ${ }^{240}$ and trans leaders hold public office. ${ }^{241}$ Public opinion supports expanding substantive due process doctrine to ensure people of all gender identities may live freely under the law, even if the voices of an intolerant minority may be loud. In the Court's own words, "Our obligation is to define the liberty of all, not to mandate our own moral code." 242 Considering historical applications of substantive due process with today's growing movement for trans equality, the right to live freely according to one's gender identity should be considered a fundamental right worthy of heightened protection.

\section{Defending the Right Under Judicial Scrutiny}

Assuming, arguendo, that the right to live freely according to one's gender identity is a fundamental right, infringements upon that right should not easily survive legal challenges. As discussed above, a non-legislative deprivation of a fundamental right fails a due process challenge when the plaintiff demonstrates a deliberate and arbitrary abuse of government power. ${ }^{243}$ To uphold a challenge, a court must find that the deprivation of a fundamental right was "arbitrary, irrational, or tainted by improper motive" 244 or "so egregious, so outrageous, that it may fairly be said to shock the contemporary conscience." ${ }^{245}$ Legislative infringements upon fundamental rights must pass strict

\footnotetext{
${ }^{240}$ See, e.g., Weightlifter Hubbard Becomes Lightning Rod for Criticism of Transgender Policy, ReUTERS (July 30, 2019), https://www.reuters.com/article/us-weightlifting-newzealand-hubbard/weightlifter-hubbardbecomes-lightning-rod-for-criticism-of-transgender-policy-idUSKCN1UP0F0 [https://perma.cc/UL8ZW6PQ].

${ }^{241}$ Transgender individuals have held public office in the United States for decades. Marwa Eltagouri, Transgender People Have Been Elected Before. But They Can Finally Let the Voters Know., Wash. Post (Nov. 9, 2017), https://www.washingtonpost.com/news/retropolis/wp/2017/11/08/transgender-people-havebeen-elected-before-but-they-can-finally-let-the-voters-know/ [https://perma.cc/CP36-7A9R]. Only recently, with growing cultural tolerance, has it become possible for transgender public officials to serve - and get elected - openly. Id. November 7, 2017, was an historic moment: Americans elected at least eight transgender candidates to public office that day. Meet the Transgender Americans Who Won on Election Day, Hum. RTS. CAMPAIGN (Nov. 8, 2017), https://www.hrc.org/blog/meet-the-transgender-americans-who-wonon-election-day [https://perma.cc/J5YV-PNSY].

${ }^{242}$ Planned Parenthood of Se. Pa. v. Casey, 505 U.S. 833, 850 (1992).

${ }^{243}$ Midnight Sessions, Ltd. v. City of Phila., 945 F.2d 667, 683 (3d Cir. 1991).

${ }^{244}$ Nicholas v. Pa. State Univ., 227 F.3d 133, 139 (3d Cir. 2000).

${ }^{245}$ Pioneer Aggregates, Inc. v. Pa. Dep't of Env’t Prot., No. 11-cv-00325, 2012 U.S. Dist. LEXIS 135550, at *22 (M.D. Pa. Sept. 21, 2012) (quoting Cnty. of Sacramento v. Lewis, 523 U.S. 833, 847 (1998)).
} 
scrutiny to be constitutionally valid. ${ }^{246}$ The Due Process Clause "forbids the government to infringe ... 'fundamental' liberty interests at all, no matter what process is provided, unless the infringement is narrowly tailored to serve a compelling state interest." ${ }^{247}$

Regardless of a court's chosen standard, the right to live freely withstands even the toughest scrutiny. Advocates may argue that there are no compelling state interests served by any deprivation of the right to live freely according to one's gender identity, and that any infringement cannot be "narrowly tailored" to serve any such interest. Advocates may also posit that actions found to deprive individuals of the right to live freely are, necessarily, arbitrary and irrational abuses of government power that are "tainted by improper motive."

Predictable arguments justifying a violation of the right are easily discreditable. In response to a due process challenge invoking the right to live freely according to one's gender identity, officials may proffer prison security and the safety and health of those who are incarcerated as legitimate and compelling state interests served by housing a preoperative trans woman in a men's prison or a trans man in a women's prison. ${ }^{248}$ But courts have rejected such arguments in the context of equal protection and some Eighth Amendment claims. ${ }^{249}$ " [G]eneralized concerns for prison security are insufficient to meet the 'demanding' burden placed on the State to justify sex-based classifications." ${ }^{250}$ Security concerns can only be "generalized," as there is no evidence trans individuals pose a greater threat to security than any others. ${ }^{251}$ "[T] ransgender prisoners should not be presumed dangerous or violent simply because they have not had genital surgery or hormone treatment." 252

\footnotetext{
${ }^{246}$ See Washington v. Glucksberg, 521 U.S. 702, 721 (1997).

${ }^{247}$ Id. (quoting Reno v. Flores, 507 U.S. 292, 302 (1993)).

${ }^{248}$ See, e.g., Hampton v. Baldwin, No. 18-CV-550, 2018 U.S. Dist. LEXIS 190682, at *35 (S.D. Ill. Nov. 7, 2018).

${ }^{249}$ See, e.g., Kosilek v. Spencer, 889 F. Supp. 2d 190, $238-39$ (D. Mass. 2012), aff'd, 740 F.3d 733, 773 (1st Cir. 2014), rev'd en banc, 774 F.3d 63 (1st Cir. 2014); Doe v. Mass. Dep't of Corr., No. 17-12255, 2018 U.S. Dist. LEXIS 99925, at *28 (D. Mass. June 14, 2018).

${ }^{250}$ Doe, 2018 U.S. Dist. LEXIS 99925, at *28 (quoting United States v. Virginia, 518 U.S. 515, 531 (1996)).

${ }^{251}$ See Hampton, 2018 U.S. Dist. LEXIS 190682, at*35.

252 Peek, supra note 33, at 1243.
} 
The practice of determining housing assignments based on genitals illustrates the weakness of the security argument. While the state certainly has a legitimate- even compelling - interest in keeping those in its custody safe from harm, studies show that trans prisoners are more often the targets of physical and sexual violence, not the perpetrators. ${ }^{253}$ A policy that fails to respect a trans individual's request to be housed with others who share their gender identity cannot be "narrowly tailored" to serve an interest in safety if that policy actually increases the risk of harm to trans prisoners. ${ }^{254}$ The same holds true for denying trans prisoners access to hormone therapy, gender-affirming surgery, clothing items, mental health counseling, and other health care. ${ }^{255}$ Instead of serving a penological interest, keeping prisoners from the care and treatment they need could harm them greatly.

Any deprivation of the right to live freely should also call into question the motiveeither explicit or implicit — of the prison official. Placing a trans individual in improper housing, consistently misgendering them, denying them transition-related health care, and limiting their access to grooming and clothing items could be motivated by transphobia. Indeed, in many instances there may be a deliberate, discriminatory motive at play. Even without such impermissible intent, these infringements upon the right to live freely can only be arbitrary, as they likely are not rationally related to any penological interest. And, importantly, stripping an individual of their constitutionally protected right to live as the person they know themselves to be should certainly "shock the conscience" of any reasonable and compassionate person.

While one could argue successfully that the right to live freely is a fundamental right and thus that violations of that right should be subject to strict scrutiny, some judges may not be convinced. Still, advocates may be able to prevail on a due process challenge. When the liberty interest at stake is not a fundamental right, courts review restrictions under the rational basis test. ${ }^{256}$ To survive judicial scrutiny, a challenged action "must be rationally related to its purpose and must not be arbitrary or discriminatory." ${ }^{257}$ Although

\footnotetext{
${ }^{253}$ See supra Part I.A for an overview of the harms faced by transgender individuals while incarcerated.

${ }^{254}$ Part I.A, supra, explores in more detail the dangers associated with housing prisoners in a manner inconsistent with their gender identity.

${ }^{255}$ See supra note 254.

${ }^{256}$ TRM, Inc. v. United States, 52 F.3d 941, 945 (11th Cir. 1995).

${ }^{257}$ Id. (quoting Silver v. Baggiano, 804 F.2d 1211, 1218 (11th Cir. 1986)).
} 
the rational basis test is not a "rigorous standard," 258 any action depriving a trans prisoner of the right to live freely according to their gender identity cannot withstand judicial scrutiny. There is no penological interest that can be rationally served by policies infringing upon this right. As discussed above, interests in prison security, preventing violence, or related goals are not served by housing trans prisoners incongruously with their gender identity. Nor are they served by denying prisoners medically necessary health care or by otherwise treating prisoners as if they are someone they are not.

Admittedly, the rational basis test is fairly lenient, and it cannot be said for certain that judges will respond favorably to a right to live freely claim if they decide that rational basis is the proper legal standard. And given the consistent application of the Turner standard, ${ }^{259}$ which has been applied to Fourteenth Amendment claims by prisoners under the right to privacy, ${ }^{260}$ it is possible that a judge would automatically apply rational basis review to a substantive due process claim by any prisoner-trans or not. But, as discussed above, infringements upon the right to live freely are usually arbitrary and motivated by at least implicit prejudice against transgender people. Violating the right can only rarely, if ever, be rationally related to a legitimate state interest. $^{261}$

\section{The Right to Live Freely as Compared to Other Constitutional Claims}

Advocates should consider utilizing the framework discussed in Part III.B because it has the potential to be a powerful legal tool for upholding the rights of transgender prisoners. First, it would allow plaintiffs to eschew some of the difficulties associated with other types of claims. Because the framework does not arise out of the Eighth Amendment, litigants who use it would no longer be reliant on the deliberate indifference standard, which is a problematic test for trans prisoners. ${ }^{262}$ It also relies on a modern conception of gender instead of outdated assumptions, unlike much of the existing

\footnotetext{
${ }^{258} I d$.

${ }^{259}$ See supra note 57 and accompanying text.

${ }^{260}$ See supra note 118 and accompanying text.

${ }^{261}$ See supra notes $250-252$ and accompanying text.

${ }^{262}$ See supra Part II.A for an explanation of the difficult Eighth Amendment legal standards.
} 
precedent on the right to privacy. ${ }^{263}$ And, because it is new, it is not bound by challenging precedent and subject to exacting standards like equal protection claims. ${ }^{264}$

The right to live freely also resolves the problems with existing frameworks identified in Part II.C, because the nature of the right embraces self-identified gender alone. This is true for multiple reasons. First, a person's "legal" gender should not alter the strength of their legal claim; neither a gender marker on a driver's license nor a traditionally gendered name reveals a person's true gender identity. Second, a person's perceived gender expression or characteristics should play no part in legal analysis, asagain - they do not determine a person's gender identity. Finally, as is now understood, gender identity is independent of biological characteristics. ${ }^{265}$ Thus, the new framework should not prove more successful among plaintiffs who have had gender-affirming surgery versus plaintiffs who have not.

\section{Using the Framework Inside Prison Walls and Beyond}

In addition to being a favorable option for prisoners as compared to more traditional forms of relief, the right to live freely may be widely applicable to incarcerated and nonincarcerated people alike. First, the right to live freely is an appropriate claim for transgender individuals facing a range of mistreatment in prison. Importantly, it may be a viable option for prisoners who have been assigned housing that is inconsistent with their gender identity. Few trans prisoners have sued prison officials seeking an affirmative injunction ordering officials to transfer them to a facility aligning with their gender identity. ${ }^{266}$ In each case, the state corrections department agreed to the transfer before a judge ruled on the merits. ${ }^{267}$ It remains to be seen how judges might treat a similar claim

\footnotetext{
${ }^{263}$ See supra Part II.B.1 for an analysis of the problems with the right to privacy in this context.

${ }^{264}$ See supra Part II.B.2 for a discussion of equal protection standards.

${ }^{265}$ See supra note 1.

${ }^{266}$ Sonia Doe's lawsuit is the most recent effort. See Brief in Support of Order to Show Cause with Temporary Restraints, supra note 13; see also Hampton v. Baldwin, No. 18-CV-550, 2018 U.S. Dist. LEXIS 190682, at *2 (S.D. Ill. Nov. 7, 2018); Doe v. Mass. Dep't of Corr., No. 17-12255, 2018 U.S. Dist. LEXIS 99925 , at $* 2$ (D. Mass. June 14, 2018).

${ }^{267}$ ACLU of N.J., supra note 14; Michael Levenson, Transgender Inmate Moved to Women's Prison, Bos. GLOBE (Jan. 25, 2019), https://www.bostonglobe.com/metro/2019/01/24/transgender-inmate-moved-womenprison/Nf2k5Oqa3Ojnh1yH1IwWkL/story.html [https://perma.cc/F4T2-BF7B] (detailing the transfer of the plaintiff in Doe, 2018 U.S. Dist. LEXIS 99925, to a women's prison); Angie Leventis Lourgos, Transgender
} 
asserting the right to live freely, but the framework proposed in this Note may be a promising option for people like Sonia bringing claims at the federal level. The idea is simple: Housing a transgender woman in a men's facility violates her constitutional right to live freely as a woman.

The applicability of the framework does not end with housing. The framework may also be valuable to plaintiffs who have been denied access to medical care related to their transition while in prison. Denying a trans prisoner who identifies as a man access to medical treatment to affirm his gender - including surgery or hormone therapy-violates his constitutional right to live freely as a man. Prisoners may also consider employing the framework to challenge infringements of the right in other contexts this Note does not explore in detail.

The benefits of this framework for trans prisoners and prisoners in general are clear, in part because of the problems with relying on other types of standards like the Eighth Amendment. But it may also be applicable — and useful —outside prison gates. One clear example is claims involving school bathroom policies. Denying a child who identifies as a girl access to the women's restroom at school may constitute a violation of her constitutional right to live freely according to her own gender identity. Unlike in the prison context, the right to privacy has been helpful to transgender students in this area. Assertions of the right to privacy tend to fail as a means of challenging trans-inclusive educational policies. ${ }^{268}$ As discussed earlier, however, that failure does not necessarily mean this doctrine is favorable to trans plaintiffs. ${ }^{269}$ Using the right to live freely may be an effective way to articulate claims in this and other areas.

\section{E. Areas for Further Consideration}

The proposed framework, as in most areas of the law, is not a perfect one. It raises some important questions of inclusivity and reliability. This section considers the applicability of the framework to nonbinary individuals, potential concerns about fraud,

Inmate Moved to Illinois Women's Prison After Alleging Years of Abuse, CHI. TRIB. (Dec. 27, 2018), https://www.chicagotribune.com/news/ct-met-transgender-prisoner-transfer-illinois-20181227-story.html [https://perma.cc/SLJ2-NMHJ] (explaining the transfer of the plaintiff in Hampton, 2018 U.S. Dist. LEXIS 190682).

${ }^{268}$ See, e.g., Parents for Priv. v. Dall. Sch. Dist. No. 2, 326 F. Supp. 3d 1075, 1099 (D. Or. 2018) (“"[H]igh school students do not have a fundamental privacy right to not share school restrooms, lockers, and showers with transgender students whose biological sex is different than theirs.").

${ }^{269}$ See supra Part II.B.1. 
whether the right to live freely is functionally the same as a right to gender expression, and, finally, barriers to litigating under the framework as a result of jurisprudence related to conditions of confinement. These potential problems have potential solutions, and, in any event, they do not prevent the framework proposed in Part III.B from providing a better set of tools with which trans prisoners may challenge unjust treatment than more commonly utilized legal paths.

\section{Implications for Nonbinary Individuals}

One question raised by this proposal is where people who identify outside of the gender binary may fit. The United States does not have "gender-neutral" or "all-gender" prison facilities, so assigning housing based on gender identity is not so simple for all prisoners. As with trans women and men, nonbinary prisoners also face more problems than just challenges with housing placement. For example, one author has described the plight of an individual incarcerated in the United Kingdom:

Nathan ... is housed in a men's prison, but is bi-gendered and since childhood has felt male on some days and female on others. But due to not identifying as a woman full time, Nathan has been denied access to women's clothes. Nathan tried to buy gender-neutral clothing but explained this was difficult because of "limited access to clothing retail catalogues.",270

Nathan is incarcerated abroad, but their struggle echoes that of individuals in the United States.

Housing nonbinary prisoners separately from men and women may not be the most just solution. Depending on how many prisoners identify outside the binary, ${ }^{271}$ segregated

\footnotetext{
${ }^{270}$ Harris, supra note 223.

${ }^{271}$ Data analyzing the number of prisoners who identify outside the gender binary may be unavailable or unreliable, particularly because some comprehensive surveys of transgender prisoners' experiences lump nonbinary individuals in with transgender women and men. See, e.g., JAMES ET AL., supra note 23, at 23. Part of the reason an accurate estimate of the number of nonbinary prisoners is difficult to obtain is that people use a wide variety of labels for their own identities. Some people even use multiple labels to describe themselves. See id. at 44. The results of a comprehensive recent National Center for Transgender Equality survey illustrate this phenomenon: Eighty-eight percent of the 28,000 respondents voluntarily described themselves as "transgender," yet thirty-one percent checked "non-binary" when asked to identify the terms they use to describe their gender identity from a list. Id. If those numbers seem hard to reconcile, then the possibility of a precise count of nonbinary or genderqueer incarcerated people remains elusive.
} 
housing may come with some of the consequences of solitary confinement. As previously discussed, the potential for trauma as a result of living in solitary confinement ${ }^{272}$ far outweighs any benefit, be it isolation from physical safety risks or for the sake of respecting identity. More realistically, there is likely a sizeable group of prisoners who would feel most comfortable in a gender-neutral facility. ${ }^{273}$ The answer to this problem lies outside the scope of this Note and is perhaps one that is too complicated for the Due Process Clause to answer on its own. Undoubtedly there need to be more protective policies in place to ensure nonbinary prisoners - as well as trans individuals who identify as women or men - are able to live in their true gender while remaining safe from undue harm while incarcerated.

Regardless of what hypothetical future laws or policies might protect nonbinary prisoners to the greatest extent possible, recognizing a right to live freely under the Due Process Clause will likely help. Perhaps nonbinary plaintiffs can use the framework to argue for gender-neutral housing options, if there is enough demand to deem such an option favorable. The right to live freely might also help prisoners obtain access to gender-neutral clothing and other essential items. The current legal landscape lacks protections for nonbinary people as much as it does trans women and men, and nonbinary individuals should no longer be excluded from the conversation.

\section{Potential for Fraud}

Another concern might be that recognizing this right would create opportunities for fraudulent claims. One might allege that a prisoner could lie about being transgender in order to be transferred to an opposite-gender facility. Any such concern is likely to be overstated. While fears of "gender fraud" may have been prevalent in the past, modern understandings have quelled them to a significant degree. ${ }^{274}$ In non-prison contexts, these fears have proven unfounded: Based on nearly forty years of data revealing zero

\footnotetext{
${ }^{272}$ See supra Part I.A for a discussion of the grave dangers of time spent in solitary confinement.

${ }^{273}$ One author advocates for a "separate (but not solitary) wing within an otherwise single-sex prison, open only to" trans, non-binary, gender-nonconforming, and intersex individuals, considering that the current prison model lacks the requisite infrastructure for accommodation in solely male or female facilities. Jessica Szuminski, Behind the Binary Bars: A Critique of Prison Placement Policies for Transgender, Non-Binary, and Gender Non-Conforming Prisoners, 105 MiNN. L. ReV. 477, 515 (2020).
}

${ }^{274}$ See Jo Wuest, The Scientific Gaze in American Transgender Politics: Contesting the Meanings of Sex, Gender, and Gender Identity in the Bathroom Rights Cases, 15 POL. \& GENDER 336, 351 (2019) (noting a shift in the last few decades away from state concerns of gender fraud to concerns about the medical "permanence" of transgender identity). 
instances of fraud, the National Collegiate Athletic Association said it is a "myth" that people pretend to be transgender to gain an advantage in competitive sports. ${ }^{275}$ And as schools increasingly implement gender-inclusive bathroom policies, law enforcement officials have not seen any uptick in sexual assaults. ${ }^{276}$ What is more likely is that existing jurisprudence and institutional policy already overcompensate for this concern.

\section{A Right to Free Gender Expression}

Third, one could contend that a right to live as one's inherent gender is essentially the same as a right to freedom of gender expression. That area of law has not been friendly to people bringing claims based on their transgender status. ${ }^{277}$ But much of the constitutional law surrounding gender expression falls under the Equal Protection Clause or Title VII. Courts have maintained for decades that gender stereotyping is actionable as sex discrimination under Title VII. ${ }^{278}$ The vulnerability of equal protection jurisprudence protecting gender identity under the current Supreme Court is explored earlier in this Note. The right to live freely according to one's gender identity is a liberty protected by the Due Process Clause, which involves different — and potentially more favorable-legal standards. Additionally, the right to live freely does not invite considerations of visible gender characteristics, whereas gender expression may do so. As discussed in Part II.C, we should strive to divorce a protective legal framework from these factors.

\section{Barriers to Challenging Conditions of Confinement}

One more potential obstacle to bringing this type of claim to challenge certain actions by prison officials is that some courts have rejected due process claims related to conditions of confinement on the ground that the Eighth Amendment is the proper avenue

\footnotetext{
${ }^{275}$ Elizabeth M. Ziegler \& Tamara Isadora Huntley, It Got Too Tough to Not Be Me: Accommodating Transgender Athletes in Sport, 39 J. ColL. \& UnIV. L. 467, 486 (2013).

${ }^{276}$ Katy Steinmetz, Why LGBT Advocates Say Bathroom 'Predators' Argument Is a Red Herring, TIME (May 2, 2016), https://time.com/4314896/transgender-bathroom-bill-male-predators-argument/ [https://perma.cc/9WNM-6YHS]; see also What Experts Say, NAT'L CTR. FOR TRANSGENDER EQUAL., https://transequality.org/what-experts-say [https://perma.cc/2GWU-D97Q].

${ }^{277}$ See supra Part II.B.2 for a discussion of transgender litigation under the Equal Protection Clause.

278 Price Waterhouse v. Hopkins, 490 U.S. 228 (1989).
} 
for redress. ${ }^{279}$ "Changes in the conditions of confinement having a substantial adverse impact on the prisoner are not alone sufficient to invoke the protections of the Due Process Clause 'as long as the conditions or degree of confinement to which the prisoner is subjected is within the sentence imposed upon him." ${ }^{280}$ For example, the Court in Montanye v. Haymes held that prisoners have no protected liberty interest in remaining in a particular prison facility, as transfers are "within the sentence imposed upon" them. ${ }^{281}$ In Hewitt v. Helms, the Court similarly reasoned that administrative segregation, or solitary confinement, was "the sort of confinement that inmates should reasonably anticipate receiving at some point." 282

With some claims, such as challenging a housing placement decision, a judge might consider the controversy to implicate conditions of confinement, barring a due process challenge. The solution then would be to make clear that placement that is inconsistent with gender identity falls outside of the Montanye standard. Prisoners should not be forced to give up essential pieces of their identity while they are incarcerated, and correcting a housing assignment does not mean that the person is no longer serving a prison sentence.

\section{F. Remembering the Goals of Abolition}

Finally and importantly, it is critical to emphasize that while this Note proposes what is essentially a legal workaround to improve the current system, we must not forget the valid calls for prison abolition. Scholars and activists including Ruth Wilson Gilmore, Angela Davis, and Mariame Kaba envision a "restructured society" that invests directly in communities and social services instead of in carceral punishment. ${ }^{283}$ One notable

\footnotetext{
${ }^{279}$ See Meriwether v. Faulkner, 821 F.2d 408, 414 (7th Cir. 1987) (“The Supreme Court has on numerous occasions held that an inmate's treatment by prison authorities is rarely subject to judicial oversight under the Due Process Clause.”).

${ }^{280}$ Vitek v. Jones, 445 U.S. 480, 493 (1980) (quoting Montanye v. Haymes, 427 U.S. 236, 242 (1976)).

${ }^{281}$ Montanye, 427 U.S. at 242.

${ }^{282}$ Hewitt v. Helms, 459 U.S. 460, 468 (1983). The Court went on to find that the plaintiff had a protected liberty interest under the Due Process Clause in remaining in the general population, grounding that conclusion in the "unmistakably mandatory character" of the state regulatory scheme's procedural requirements surrounding administrative segregation. Id. at 472 .

283 See Elias Rodriquez, Abolition Is a Collective Vision: An Interview with Mariame Kaba, NATION (Mar. 29, 2021), https://www.thenation.com/article/culture/mariame-kaba-interview-til-we-free-us/; Gabriella
} 
outgrowth of the abolitionist movement is activists' recent call to "defund the police" in response to the murder of George Floyd, a Black man, by Minneapolis police last summer. The basic idea behind the defund movement is to "cut the astronomical amount of money that our governments spend on law enforcement and give that money to more helpful services like job training, counseling, and violence-prevention programs." 284

Strengthening legal protections for vulnerable populations, including trans folks, may be understood as a small step in the "long game" of abolition. ${ }^{285}$ Recognition of the right to live freely would certainly be a victory for all trans people and has the potential to tangibly improve people's lives. But incremental victories should not obscure our ultimate goals, which should include an end to the prison-industrial complex, secure access to social services for low-income and marginalized communities, and a society that actively resists hatred and intolerance.

\section{CONCLUSION}

Transgender prisoners are among the most vulnerable populations in the United States. Yet, despite decades of mistreatment by state and federal prison officials, courts have generally been unfavorable to their legal challenges and have not adapted to the thriving movement for transgender equality in this country and beyond. The types of claims traditionally relied upon by trans individuals - including the Eighth Amendment, right to privacy, and equal protection - continue to disappoint plaintiffs who have suffered constitutional violations while incarcerated. As more trans prisoners like Sonia Doe seek relief in the form of housing transfers aligning with their gender identity, we must consider a new constitutional framework. Trans plaintiffs and their advocates should assert the right to live freely according to one's gender identity under the Due Process Clause. In the interests of Justice and the promotion of the general Welfare, ${ }^{286}$

Paiella, How Would Prison Abolition Actually Work?, GQ (June 11, 2020), https://www.gq.com/story/whatis-prison-abolition [https://perma.cc/E7T5-6W3F] (interviewing abolitionist organizer Woods Ervin in the wake of civil rights protests after the police killing of George Floyd). See generally ANGELA Y. DAVIS, ARE PRISONS OBSOLETE? (2003) (calling for decarceration and explaining the racist origins and underpinnings of the current prison system).

${ }^{284}$ Paige Fernandez, Defunding the Police Will Actually Make Us Safer, ACLU (June 11, 2020), https://www.aclu.org/news/criminal-law-reform/defunding-the-police-will-actually-make-us-safer/ [https://perma.cc/2327-SEGP].

${ }^{285}$ See Ruth Wilson Gilmore \& James Kilgore, The Case for Abolition, Marshall Project (June 19, 2019), https://www.themarshallproject.org/2019/06/19/the-case-for-abolition [https://perma.cc/F4L3-ALKF].

${ }^{286}$ U.S. CONST. pmbl. 
our Constitution should powerfully uphold the rights of transgender prisoners in the face of violence against their most basic senses of self. 